\title{
Neurogenetic effects on cognition in aging brains: a window of opportunity for intervention?
}

\author{
Ivar Reinvang ${ }^{1}$, Ian J. Deary ${ }^{2}$, Anders M. Fjell ${ }^{1}$, Vidar M. Steen ${ }^{3,4}$, Thomas Espeseth ${ }^{1}$ and Raja Parasuraman ${ }^{\text {* }}$ \\ Department of Psychology, University of Oslo, Oslo, Norway \\ Department of Psychology, University of Edinburgh, Edinburgh, UK \\ 3 Department of Clinical Medicine, University of Bergen, Bergen, Norway \\ ${ }^{4}$ Center for Medical Genetics and Molecular Medicine, Haukeland University Hospital, Bergen, Norway \\ ${ }^{5}$ Department of Psychology, George Mason University, Fairfax, VA, USA
}

\section{Edited by:}

Arthur F. Kramer, University of Illinois at Urbana-Champaign, USA

Reviewed by:

Naftali Raz, Wayne State University, USA

Terry E. Goldberg, Feinstein Institute/ AECOM, USA

\section{*Correspondence:}

Raja Parasuraman, Department of Psychology, George Mason University, 4400 University Drive, MS 3F5, Fairfax, VA 22030, USA.

e-mail: rparasur@gmu.edu
Knowledge of genetic influences on cognitive aging can constrain and guide interventions aimed at limiting age-related cognitive decline in older adults. Progress in understanding the neural basis of cognitive aging also requires a better understanding of the neurogenetics of cognition. This selective review article describes studies aimed at deriving specific neurogenetic information from three parallel and interrelated phenotype-based approaches: psychometric constructs, cognitive neuroscience-based processing measures, and brain imaging morphometric data. Developments in newer genetic analysis tools, including genome wide association, are also described. In particular, we focus on models for establishing genotype-phenotype associations within an explanatory framework linking molecular, brain, and cognitive levels of analysis. Such multiple-phenotype approaches indicate that individual variation in genes central to maintaining synaptic integrity, neurotransmitter function, and synaptic plasticity are important in affecting age-related changes in brain structure and cognition. Investigating phenotypes at multiple levels is recommended as a means to advance understanding of the neural impact of genetic variants relevant to cognitive aging. Further knowledge regarding the mechanisms of interaction between genetic and preventative procedures will in turn help in understanding the ameliorative effect of various experiential and lifestyle factors on age-related cognitive decline.

Keywords: aging, cognition, genetics, interventions, neuroimaging, psychometrics

\section{INTRODUCTION}

As a group, older individuals typically perform more poorly than younger adults in most (but not all) tests of mental functioning. Empirical investigations and reviews highlight speed of processing, executive functioning, and working memory as central to normal, age-related decline (Park and Reuter-Lorenz, 2009). Episodic memory is also affected, but more so in disorders of aging such as Alzheimer's disease (AD) than in normal aging (Buckner, 2004). There is some debate as to when, on average, such cognitive aging is first detectable. Longitudinal research indicates that age-related cognitive decline begins only after about 60 years, while cross-sectional studies propose an earlier onset, perhaps as early as 30 years (Park et al., 2002; Salthouse, 2009; Schaie, 2009). But irrespective of the age at which cognitive decline is first seen, researchers agree that there are substantial individual differences in cognitive aging: Some persons show considerable deterioration in cognitive performance as they age while others show little or no decline, and a small minority may even be superior to their younger counterparts (Hillman et al., 2006).

What are the factors contributing to such individual variation in the pattern of cognitive aging? Furthermore, what can be done to develop appropriate preventative efforts directed at those most likely to exhibit cognitive decline? Changes in brain plasticity whether due to genetic or environmental factors, or a combination of the two - probably play an important role in explaining such individual variability in cognitive aging (Kramer et al., 2004; Burke and Barnes, 2006).

\section{WHAT NEUROGENETIC STUDIES CAN OFFER}

Knowledge of genetic influences on cognitive aging can constrain and guide interventions aimed at limiting age-related cognitive decline in older adults. Progress in understanding the neural basis of age-related cognitive change will also depend on a better understanding of the neurogenetics of cognition and of neurobiological mechanisms underlying normal and pathological aging. Recent studies have pointed to considerable plasticity and capacity for reorganization in aging brains, both at behavioral and neuronal levels (Greenwood, 2007; Park and Reuter-Lorenz, 2009; Payton, 2009). An important challenge for future research, and a focus of this review article, is to determine how knowledge of genetic influences can be used to develop or modify interventions aimed at limiting age-related cognitive decline through a better understanding of the neural impact of genetic variants relevant to cognitive aging.

The central role of genetics in cognitive aging is supported by empirical evidence from twin studies that point to a high degree of heritability of both general cognitive ability (McClearn et al., 1997; Deary et al., 2006, 2009a,b) and specific cognitive functions (Fan et al., 2001; Swan and Carmelli, 2002). Heritability estimates for cognitive traits tend to increase with age from early childhood to adolescence and young adulthood, and the additive genetic contribution to general cognitive ability and broad cognitive traits remains high (greater than 50\%) in middle and old age. High estimates of heritability are also found for global brain morphomet- 
(Toga and Thompson, 2005; Deary et al., 2010) and, with some variation, also for anatomical subdivisions of the brain (Sullivan et al., 2001). Brain markers of cognitive processing such as eventrelated potentials (ERPs) likewise show substantial heritability (Almasy et al., 2001), as do components of the electroencephalogram (EEG) (Posthuma et al., 2001; Smit et al., 2010).

\section{LIMITATIONS AND PROBLEMS IN NEUROGENETICS}

Over a century of behavior genetic studies using the twin method and the last decade of molecular genetic studies of normal adults and neuropsychiatric groups have provided an extensive database of findings on genetic contributions to variation in cognitive functioning (Plomin and Crabbe, 2000; Goldberg and Weinberger, 2004; Parasuraman and Greenwood, 2004; Green et al., 2008). Despite this extensive research, efforts to identify genetic mechanisms at the single gene level for traits with high heritability have run into considerable problems (Payton, 2009; Deary et al., 2010). Similar difficulties have plagued genetic studies of numerous neuropsychiatric disorders (Tan et al., 2008).

Single gene studies have faced problems of small effect sizes and frequent lack of replication. Genetic association studies of neuropsychiatric disease, for example, often report very low $(\sim 0.01)$ effect sizes (Ioannidis et al., 2001). This has lead to the current rush toward expensive, large-scale genome wide association studies (GWAS), which we discuss in a later section of this paper. To date, the GWAS approach has not provided clear solutions to the problems associated with genetic association studies of normal cognition or disease. Despite this, one fact provides an encouraging sign with respect to future progress in genetic studies of cognitive aging - that individual differences in cognitive functioning remain highly heritable in older adults. Such heritability could reflect largely stable traits present from the time of childhood. A more likely possibility - since cognitive heritability increases with age - is that genetic contributions to individual differences in cognitive functioning in older adults reflect specific age-related influences that are absent in (or different to) that in younger individuals. The APOE gene, whose influences on cognition we discuss in later sections of this paper, could represent one such major age-specific genetic effect. That is, if apolipoprotein $E$ is involved in neuronal repair after damage (Mahley et al., 2006), and if variants of the gene produce isoforms with different repair efficiency, then it would be expected that differential effects in neural and cognitive functions might emerge only after years in which the cumulative effects of these differences became apparent. Such agedependent penetrance of a phenotypic effect is commonly observed in many monogenic disorders.

Another critical issue for progress in neurogenetic studies of cognitive aging is the identification and selection of appropriate phenotypes. Several researchers have discussed this issue, with differing recommendations (Bilder et al., 2009). Goldberg and Weinberger (2004) proposed criteria for considering cognitionbased phenotypes as good candidates for a genetic association study, including evidence for heritability, good test-retest reliability, and known neurobiology that can plausibly be related to candidate gene effects. From the point of view of the current article, one would add that the phenotype should also be sensitive to aging, including accelerated age-related decline. Meyer-Lindenberg and Weinberger (2006) advocate functional neuroimaging phenotypes as a guide to the discovery of neural circuitry that translates genetic effects into behavior. These investigators were less concerned with heritability of the imaging probe used, so long as it instantiates a plausible neurobiological mechanism, which in the present context would be a relationship to cognitive aging. Greenwood and Parasuraman (2003) expressed a similar view, stating that, for several functions, knowledge of brain networks and corresponding innervation can be used to guide selection of SNPs in neurotransmitter genes. They argued that good phenotype candidates for revealing genetic associations can be derived from cognitive neuroscience paradigms. Deary et al. (2010) and the Consortium for Neuropsychiatric Phenomics (CNP, Sabb et al., 2009) use statistical and informatics tools to systematize and distil shared functional components from psychometric test batteries from which a large amount of information is available from generations of clinical and aging studies of large samples. While poorly defined phenotypes are most clearly evident at the level of cognitive concepts, ill-defined phenotypes occur at all levels of inquiry, including neural systems (Sabb et al., 2009).

Variation in sample characteristics represents another important factor that can limit the efficacy of genetic association studies of cognitive aging (Payton, 2009). Representative population-based samples typically differ significantly from convenience-based samples, which in Western European countries contain an overrepresentation of well educated women and participants with above average IQ. Ethnicity is also important, and for genes of interest with respect to cognitive aging such as APOE, there are major differences in allele frequencies between ethnic groups. At least in the context of pathology these variations have different associations with risk, so that a population with a high incidence of APOE $\varepsilon 4$ may show a weak effect of $\varepsilon 4$ carrier status on risk of dementia (Gureje et al., 2006), which in other populations are associated with a high risk effect (Raber et al., 2004). These are general issues affecting the whole field of cognitive and neuropsychiatric genetics. With respect to the neurogenetics of cognitive aging, considerations of what are the typical and possibly most plastic age-related changes must constrain further discussion.

\section{OVERVIEW OF THE PRESENT ARTICLE}

This paper presents efforts to derive specific neurogenetic information from multi-phenotype-based approaches. Psychometric constructs, cognitive neuroscience-based processing measures, and brain imaging morphometric data represent three key approaches that can be interrelated to better explore the neurogenetics of cognitive aging. In addition, interpreting the results in a genetic context requires an update of developments in genetic analysis tools, and models for establishing genotype-phenotype association within an explanatory framework including plausible links between molecular, brain, and cognitive levels of analysis. Accordingly, after describing representative results from the three approaches, we discuss the implications of the newly emerging genetic tools for the cognitive neurogenetics of aging.

Several broad and comprehensive reviews of this field have recently been published (Greenwood and Parasuraman, 2003; Payton, 2009; Deary et al., 2010). Furthermore, reports of new genetic association findings are continuously being published. Many of these prove to not be replicable (Payton, 2009). The present 
article will focus on a selection of the most intensively studied genetic variants, for which data are available from all the three approaches discussed here. We also highlight data mainly from studies by the present group of authors, who are collaborating on a joint project examining the contributions of cognitive neuroscience and neurogenetics to the study of cognitive aging. Our focus differs from previous reviews in that we emphasize the importance of investigating phenotypes at multiple levels: such an approach allows for an assessment of the neural impact of genetic variants that are relevant to an understanding of cognitive aging and of interventions aimed at reducing age-related cognitive decline.

\section{GENES AND GENOTYPES}

The apolipoprotein E gene (APOE) is the most intensively studied gene in the cognitive aging and neurogenetics literature. There are three different alleles $(\varepsilon 2, \varepsilon 3$, and $\varepsilon 4)$ of APOE. Carriers of the $\varepsilon 4$ allele are at increased risk for developing $\mathrm{AD}$ in a gene dose dependent manner (Corder et al., 1993) and also have a dose dependent increased risk of an earlier disease onset (Raber et al., 2004). In addition to the impact on $\mathrm{AD}$ pathology, apolipoprotein $\mathrm{E}$ can influence normal brain structure and function by affecting synaptic generation and other restorative mechanisms involving cholesterol transport and metabolism (Mahley et al., 2006). Cognitively normal older adults with the $\varepsilon 4$ allele show lowered cerebral glucose metabolism as indexed by positron emission tomography (PET) in the same cortical regions as clinically diagnosed AD patients (Reiman et al., 1996). The same regional abnormalities were reported in a study of healthy young $\varepsilon 4$ carriers in their 20 s and 30s (Reiman et al., 2004), pointing to the possibility of a very long prodromal period for $\mathrm{AD}$ development. Recent findings (Reiman et al., 2009; Small et al., 2009) indicate that increased accumulation of $\mathrm{AD}$ pathology (fibrillar amyloid $\beta$ and tau proteins) is found in cognitively normal APOE $\varepsilon 4$ carriers of age $60-70$, indicating that a clear distinction between normal and pathological effects of APOE $\varepsilon 4$ on typical cognitive aging may not be possible.

Brain-derived neurotrophic factor (BDNF) has a welldocumented function in hippocampal learning mechanisms (Egan et al., 2003; Gooney et al., 2004) and plays an important role in brain development. Studies by Hariri et al. (2003) and Pezawas et al. (2004) have indicated an effect of a specific SNP in this gene (rs6265) on episodic memory performance and on brain morphology, including hippocampal volume and prefrontal cortex volume. BDNF is integrated in a cascade of genetic effects influenced by SNP variation in regulatory genes (Le Hellard et al., 2009).

Cathecol-O-methyl-transferase (COMT) is a gene controlling bioavailability of dopamine in the synaptic cleft, where a specific SNP (rs4680) is associated with a less stable form of the enzyme. Variation in this SNP has been associated with working memory capacity and activation of prefrontal cortex during tasks requiring short-term retention and manipulation of information. COMT is the most widely studied member of the class of neurotransmissionrelated genes, and increased focus on this gene is partly influenced by the strong interest in dopaminergic mechanisms in neuropsychiatry. Payton (2009) observed that studies of neurotransmitter genes (including BDNF) account for two-thirds of the publications in the field of cognitive neurogenetics in healthy populations. Other neurotransmission genes may be of equal relevance in normal cognitive aging, where cholinergic, noradrenergic, and glutamatergic mechanisms may be associated with function in specific cognitive domains (Fan et al., 2003; Greenwood et al., 2005a, 2009a,b; Parasuraman et al., 2005; Espeseth et al., 2007; Winterer et al., 2008).

\section{MODELS FOR GENE-COGNITIVE AGING ASSOCIATIONS}

Models by which an increase or change in the pattern of genetic influence may be seen in old compared to young adults persons may firstly recognize the plasticity of gene function, and the possibility that patterns of gene expression changes with age. This may result in a finding of age-specific gene-cognition association patterns. Recent studies of gene expression in brain tissue from several regions of the brain indicate that there are indeed substantial differences in gene expression in old compared to young persons, and that the frontal lobes show the most marked differences (Berchtold et al., 2008). However, the changes involve a large and highly variable set of genes, so it seems unlikely that, based on changes in gene expression, one could find a consistent age-cognition pattern associated with a single SNP or even with a single gene. In line with this, it should be noted that global gene expression studies of human cortical areas have reported large inter-individual variations (Watakabe et al., 2001; Khaitovich et al., 2004), and such variation between individuals seems to be larger among humans than among chimpanzees (Khaitovich et al., 2004).

Age-related findings may result from SNP variation in genes that in themselves have small effect sizes in young people, but may assume greater importance because of age dependent biological changes. An example would be that COMT is associated with small variations in efficiency of dopaminergic functions, which may assume increasing functional significance with increasing agerelated reduction in synthesis of dopamine and loss of dopaminergic synapses (Lindenberger et al., 2008). The same line of argument may be used for cholinergic function, in which age-related loss of nicotinic receptors is well documented (Court et al., 1997; Mitsis et al., 2009). In this model the relevant SNP has age-invariant functions, but the effect of the SNP variation increases because of normal age-related neurobiological changes in brain resources.

This line of thinking may be extended to include pathological agerelated changes. While the distinction between normal and pathological neurobiological mechanisms in aging is fuzzy, most would agree that accumulation of proteinopathies ( $\beta$ amyloid and tau) in the brain is pathological. Studies by Braak and Braak (1995) indicate that a significant proportion (30-40\%) of cognitively normal persons have some accumulation of these proteins in the brain before age 60. APOE polymorphisms affect the efficiency of $\beta$ amyloid synthesis and clearance in the brain, thus paving the way for complex interactions of effects of the same gene on both normal (synaptic) and pathological processes affecting cognition. In this scenario there would be age dependent effects of APOE, but the findings would be variable according to the load of additional pathological factors.

\section{REPRESENTATIVE NEUROGENETIC STUDIES PSYCHOMETRIC STUDIES}

Psychometric cognitive tasks have properties of standardization and documented reliability and validity that make them suitable in research on individual differences. Furthermore, data are 
available from several studies with large numbers of participants, laying the ground for meta-analyses and evaluation of replicability. Batteries of psychometric tests have been extensively analyzed to reveal a latent structure of underlying factors that are candidates for explanatory constructs. These constructs must have biological plausibility and neural correlates in order to have explanatory value and avoid the fallacy of reification (Deary, 2000). Deary et al. (2010) point out that there is only a small proportion of test variance that is explained by domain specific cognitive factors, with most of the variance being attributable to a common factor to all tests $(g)$ or by highly test-specific factors. Attempts to integrate genetic association studies in terms of cognitive domains like memory, attention etc. based on conceptual grouping of reported test findings are therefore sensitive to confounding by $g$ or test specific factors. In this view, any finding of an association between a genetic variant and scores on a test of a specific cognitive domain must bear in mind that the association could be due to the genetic contribution to general cognitive ability (especially) or to testspecific variation (less so).

Comprehensive reviews of association studies with APOE have been published by Small et al. (2004) and recently updated by Wisdom et al. (2009), including 77 studies of more than 40,000 participants. They conclude that for memory there is a moderate size association with APOE carrier status, and additional associations of APOE with executive function and global cognitive ability. The difference between $\varepsilon 4$ carriers and noncarriers increase with increasing age for memory and global cognitive ability. Sabb et al. (2009) use a literature-based informatics approach to define latent constructs for which there seem to be sufficient agreement about operational definitions. They find that within the cognitive domain there is sufficient consensus for memory and intelligence to operationally define stable phenotypes. They review the results of association studies for APOE, BDNF, and COMT and conclude that for intelligence there is a weak effect of APOE, and small effects of BDNF and COMT. For memory about $75 \%$ of 22 included studies show an association of APOE $\varepsilon 4$ with poorer memory, but the effect sizes are small. For BDNF and COMT only four studies with adequate phenotypes were found, and the results are mixed. For COMT, the available results for more than 40 studies have been summarized by Barnett et al. (2008), who conclude that only a weak association with intelligence can withstand rigorous statistical tests. This conclusion has been challenged by Goldman et al. (2009) on the ground that neurobiological plausibility must be taken into consideration.

Among several Scottish and UK population-based cohorts the Lothian Birth Cohort 1936 (LBC36, Deary et al., 2007) is unique in that it includes a representative sample of 1,000 individuals born in 1936, and for whom cognitive data are available both at age 11 and age $70-80$. At age 70 (and a further follow up at age 73 is complete) data are available for tests of intellectual function (Wechsler Adult Intelligence Scales III), for memory (Wechsler Memory Scales III) and for reaction time (RT) paradigms. Processing speed measures applied to human subjects range from psychometric behavioral type tests (e.g., the Digit Symbol and Symbol Search subtests of the Wechsler Adult Intelligence Scales), through cognitive experimental assessments (e.g., simple and choice RT procedures), to psychophysical measures (e.g., inspection time). A specific aim of further investigation is to discover whether speed of information processing mediates the genetic influences on cognition at age 70 .

Studies of smaller follow-up samples from the Scottish Mental Surveys of 1932 and 1947 have reported significant contributions to variance in normal cognitive aging from variation in APOE (Deary et al., 2002), COMT (Harris et al., 2005), and BDNF (Harris et al., 2006). APOE provided a clear example of a genetic polymorphism that in the same sample was related to cognitive ability in old age but not in youth (Deary et al., 2002). Harris et al. (2006) found that BDNF genotype was significantly associated with later life Raven scores, controlling for sex and childhood IQ. This study indicated that BDNF genotype contributes to age-related changes in reasoning skills, which are closely related to general intelligence. However, the Met homozygotes scored significantly higher than heterozygotes and Val homozygotes, in contrast to findings that Met carriers have poorer memory. Starr et al. (2007) studied three waves of repeated testing between ages 64 and 68 years in a cohort of community volunteers (the Aberdeen Birth Cohort 1936, who had taken part in the Scottish Mental Survey of 1947) who had validated childhood IQ data. After adjusting for childhood IQ, wave of testing, and specific test type, COMT Val158Met polymorphism had a significant overall effect on cognition. The study adds to the evidence that the Val/Val genotype has a detrimental effect on cognition.

The LBC36 cohort has recently been extensively studied as a testing ground for replication of cognitive gene association findings. Luciano et al. (2009b) examined the association of APOE to memory and, of the eight measures tested, spatial span forward was significantly associated with APOE $\varepsilon 4$ variation when adjusting for childhood IQ, whereas Logical memory immediate was associated with APOE $\varepsilon 4$ variation in the analysis not controlling for childhood IQ. Neither of these tests was significant when a correction for multiple testing was applied. The authors concluded that APOE $\varepsilon 4$ does not influence memory abilities in a normal population of 70-year-olds. In another report Luciano et al. (2009a) analyzed APOE in relation to measures of speed of processing and working memory and found that APOE was associated with the general cognitive factor, two non-verbal tests, and choice RT variability. As expected, the $\varepsilon 4$ allele was the risk allele. With the exception of choice RT variability, they did not observe any main effect of APOE on the processing speed measures. However, the correlation between childhood ability and speed was lower in $\varepsilon 4$ allele carriers. The investigators concluded that APOE has an influence on non-verbal cognition in old age and interacts with childhood IQ to influence processing speed. Houlihan et al. (2009) selected 19 SNPs from 10 genes previously found to be associated with cognition, including BDNF and COMT, and examined them both individually and for additive effects in the Lothian Birth Cohort 1936. No effects of BDNF were found, but for COMT associations with reasoning ability and fluency were noted. They acknowledged the failure to replicate findings from a smaller sample (Harris et al., $2005,2006)$ in this larger sample.

The Norwegian Cognitive Neurogenetics sample (NCNG) is a convenience sample of healthy participants in the age range 20-80, which allows for assessment of age effects in different age ranges (Espeseth et al., 2006). The behavioral data include tests of intelligence, attention, working memory, and episodic memory, 
in addition to experimental cognitive paradigms. The use of the latter experimental tests of cognitive components contrasts with the general cognitive ability tests used in the LBC36 studies. The use of these tests, as well as the cognitive neuroscience-based tests described in the next section, is illustrative of the multiple phenotype approach discussed in this paper.

In the NCNG sample with well above average IQ ( mean = 118), APOE $\varepsilon 4$ carriers showed no memory deficits at initial testing, but in a follow-up interval of 3-5 years $\varepsilon 4$ carriers of age 60 and older exhibited greater decline in some measures of delayed verbal recall (Reinvang et al., 2010b). Reinvang et al. (2010a) used tasks of context updating and interference control to test functions involving working memory, and found that effects of APOE were modulated by gender, with reduced performance found only in male $\varepsilon 4$ carriers. Gender-related differences in age of onset of aging gene expression patterns, and evidence of interaction of APOE with androgen levels were suggested as neurobiological substrates for gender effects.

Studies of neurotransmission-related genes in the NCNG sample have so far focused on cholinergic receptor genes and interaction between APOE and a nicotinic receptor gene (CHRNA4). The evidence indicates that cognitively simple speeded tasks are sensitive to SNP variation in CHRNA4, perhaps more so in participants of age above 70 (Reinvang et al., 2009). Interaction (epistasis) of CHRNA4 with APOE influences a wider range of cognitively more complex tasks, including episodic memory (Reinvang et al., 2010b). Recognizing that BDNF is enveloped in a complex cascade of regulatory mechanisms, animal studies used to identify genes that were upregulated by BDNF during long-term potentiation (LTP) in the hippocampus, to select candidate genes for their possible influence on cognitive functioning in healthy individuals (Wibrand et al., 2006). SNPs from these genes were identified in the NCNG, LBC1921 and LBC1936 samples, and markers in the doublecortin- and calmodulin kinase like 1 (DCLK1) gene, were found to be significantly associated with general cognition (IQ scores) and verbal memory function in all cohorts (Le Hellard et al., 2009). Evidence for three regulatory associated regions on the gene was found. The findings suggest that re-analysis of the possible BDNF-DCLK1 interaction might improve the interpretation of conflicting results from BDNF association studies. Miyajima et al. (2008b) also focused on genes interacting with BDNF, and examined the RE1-silencing transcription factor (REST) gene, having the ability to downregulate the expression of a number of genes including BDNF. They found evidence of additive genetic effects in a sample that in a previous study has shown that the presence of the Met allele in BDNF Val66Met reduced performance on several cognitive tests (Miyajima et al., 2008a).

\section{COGNITIVE NEUROSCIENCE STUDIES}

Genetic studies using phenotypes based on cognitive neuroscience research provide an additional and complementary strategy to the psychometric methods described in the previous section. This approach capitalizes on the breakthroughs in understanding the neural bases of cognition that have been made possible by modern cognitive neuroscience research, particularly neuroimaging studies, which have largely followed a modular view of cognition (Fodor, 1983; Poldrack, 2008).
A good example of the modular cognitive neuroscience approach is Posner's influential "attentional network" theory. Three separate attentional functions - orienting, alerting, and executive function are linked to the activation of separate but overlapping cortical and subcortical networks (Posner and Petersen, 1990; Posner and Girolamo, 1998; Fan et al., 2005). Given evidence that at least some of these putative cognitive modules are heritable (Fan et al., 2001; Swan and Carmelli, 2002), this approach proposes that behavioral assays of these attentional networks can serve as phenotypes for molecular genetic studies. Such cognitive neuroscience phenotypes may be useful for examining genetic contributions not only to variation in normal cognition (Greenwood et al., 2000, 2005a,c; Fossella et al., 2002; Fan et al., 2003; Parasuraman et al., 2005; Parasuraman and Espeseth, 2007; Posner et al., 2007), but also to cognitive changes associated with aging and neurodegenerative disease (Parasuraman et al., 2002; Greenwood et al., 2005b; Espeseth et al., 2006).

Genetic studies using the cognitive neuroscience approach have their limitations. One is that sample sizes can be small because of factors such as the time needed to administer information-processing paradigms with many variables or the high cost of neuroimaging techniques such as MRI. Also, effect sizes in some studies are low, and there have been some failures to replicate (Green et al., 2008). But, as discussed previously, other methods share these limitations as well.

The major advantage of the approach is that the growing theoretical and empirical knowledge base in cognitive neuroscience can be used to guide and refine phenotypes for molecular genetic studies. Furthermore, information-processing and neuroimaging studies of cognitive functions can also be profitably linked to lesion, electrophysiological, and pharmacological studies of the same functions in rodent or monkey models, as a result of which clearer inter-relationships can be forged between genes, SNPs, gene expression, and neurotransmitter innervation of neurocognitive networks. With some exceptions, such human and animal linkages are difficult to establish for psychometric tests.

Consider visuospatial attention - the "orienting" component of Posner's attentional networks - as an example. Versions of the basic Posner orienting task have been administered to healthy adults, infants, and children, patients with brain lesions and neurodegenerative disorders, as well as to monkeys and rats (Posner, 2004). Neuroimaging studies have shown that a distributed brain network centered on the posterior parietal cortex plays a critical role in attentional orienting to spatial locations (Corbetta et al., 2000; Yantis et al., 2002; Fan et al., 2005). At the same time, the neurochemical innervation of this brain region and its role in attentional function has been established in animal studies that point to the importance of nicotinic cholinergic receptors (Everitt and Robbins, 1997). Nicotinic receptors (nAChRs) are important in regulating fast synaptic transmission (Alkondon et al., 2000) and play a role in attention (Levin and Simon, 1998). These receptors are composed of combinations of several alpha and beta subunits. The alpha- 4 nAChR subunit is a component of the most widely distributed nicotinic receptor in the brain, including the posterior parietal cortex, alpha-4/beta-2 (Flores et al., 1996). In a PET study, Mentis et al. (2001) also showed predominant expression of nicotinic receptors in parietal cortex. 
These findings indicate that identifying genes that are expressed in parietal cortex and influence nicotinic cholinergic function would be particularly suitable candidates for association studies of attention. One such gene is the CHRNA4 gene, which is found on chromosome 20 and is involved in the assembly of the alpha4beta- 2 subunits that form the major nicotinic receptor in parietal cortex and other cortical regions (Flores et al., 1996). Accordingly, Parasuraman et al. (2005) investigated whether polymorphisms in this gene would be associated with individual variation in performance of a visuospatial attention task that has been linked to activation of posterior parietal cortex. They examined a polymorphism involving a common $\mathrm{C}$ to $\mathrm{T}$ substitution at position 1545 (CHRNA4 C1545T) in a sample of 89 healthy adults. Participants were administered a cued letter discrimination task modeled after the orienting task introduced by Posner (1980). Cue validity (valid, invalid, neutral) was varied so that both benefits (neutral cue RT valid cue RT) and costs (invalid cue RT - neutral cue RT) of cueing could be obtained. Both RT benefits of valid cues and RT costs of invalid cues on letter discrimination varied in a systematic manner with CHRNA4 genotype. With an increased "gene dose" of the C allele (from 0 to 1 to $2 \mathrm{C}$ alleles) RT benefits increased progressively, whereas RT costs decreased, also in a similarly progressive manner. The results provided evidence for an association between the CHRNA4, and individual differences in the efficiency of shifting spatial attention in response to location cues, but the small sample size calls for replication. A subsequent study showed that the association between the CHRNA SNP and efficiency of visuospatial attention was not restricted to cued attention shifting, but was also obtained for a cued visual search task requiring changes in the size of attentional focus (Greenwood et al., 2005a). Such an association is well interpreted within a cognitive neuroscience framework because visual search also requires activation of the same posterior parietal cortical region (Corbetta et al., 1995).

These CHRNA4-attention studies were not specifically targeted at examining genetic effects in older adults. However, a subsequent study by Espeseth et al. (2006) did examine CHNRA4 effects on visuospatial attention in a sample of 230 middle-aged and older adults, both in isolation and in interaction with the APOE gene. Such an investigation was justified given evidence that the alpha-4/beta-2 $\mathrm{nAChR}$ is implicated in both normal and pathological aging. Aging in mice is associated with almost complete depletion of alpha-4 nAChR subunits in the hippocampus (Rogers et al., 1998). Human postmortem studies have shown that alpha-4 expression exhibits age-related depletion (Tohgi et al., 1998), with an additional decrease associated with AD (Martin-Ruiz et al., 1999).

Espeseth et al. (2006) administered the same cued letter discrimination task used by Parasuraman et al. (2005) to participants who were genotyped for both the CHNRNA C1545T SNP and for APOE. Relative to non-APOE- $\varepsilon 4$ carriers, individuals with the APOE- $\varepsilon 4$ allele had increased RT costs of invalid cuing, thereby replicating in a Norwegian sample earlier findings obtained with the same visuospatial attention task in United States samples (Greenwood et al., 2000, 2005c). An interaction was also observed between APOE and CHRNA4. Participants who carried the APOE- $\varepsilon 4$ allele and who were also CHRNA4 TT homozygotes showed disproportionately slowed RT following invalid location cues. The interaction is interpretable given the important role of nicotinic cholinergic receptors in attention (Levin and Simon, 1998) and the fact that cortical synthesis of acetylcholine is dependent on local availability of lipids, which are strongly influenced by APOE (Poirier, 2000). Furthermore, the interaction was stronger in the middle-aged participants than in the older participants. Previous research has also suggested that among older adults, APOE effects on cognition decrease with age (Small et al., 2004), including effects on the cued letter discrimination task (Negash et al., 2009). Espeseth et al. (2006) also found a trend for individuals with combined APOE- $\varepsilon 4 /$ CHRNA4 TT genotypes to show both lower white matter volume and slower overall RT on the attention task. The interaction of a neurotransmission gene (CHRNA4) and an Alzheimer's susceptibility gene (APOE) suggests that the efficiency of neuronal repair mechanisms may modulate the cholinergic system to influence attentional function in middle-aged and older adults.

\section{STRUCTURAL BRAIN IMAGING STUDIES}

Volumetric and other structural brain measures provide a third category of phenotype for use in neurogenetic studies of cognitive aging. Twin studies have shown that characteristics of both gray matter (GM) (Toga and Thompson, 2005) and white matter (WM) (Pfefferbaum et al., 2001; Chiang et al., 2009) are highly heritable. Further, the relationships between brain structure and cognitive performance are to a substantial degree mediated by genetic factors (Thompson et al., 2001; Posthuma et al., 2002; Chiang et al., 2009). Such findings have understandably generated wide interest in studying the effects of inter-individual genetic variations on brain function and structure. Imaging genomics is the term used for the field of research that aims to connect genetic research with imaging studies of brain structure and function.

As, with the other phenotypes, there are some limitations of the structural brain approach. Petrella et al. (2008) argued recently that most studies have been limited by small convenience samples. In addition, research in this area has typically been cross-sectional in nature as opposed to the more desirable longitudinal design. A final limitation is that many studies are exploratory in nature and lack long-term clinical correlations. Adding to the complexity is that there are almost certainly numerous genes that affect each brain structure. Selection of well-defined and biologically valid phenotypes, therefore, remains a common problem in imaging genomics as it is for cognitive neurogenetics.

\section{Effects of APOE alleles}

As in the case of cognitive studies, the $\varepsilon 4$ allele of APOE gene has also been the focus of the largest number of studies of normal aging. Due to its multiple functions, APOE may impact both GM and WM in healthy aging (Bartzokis et al., 2007). However, the direct effects of APOE on brain structure have been difficult to establish in healthy samples. Some studies have found negative effects of APOE $\varepsilon 4$ on brain volumes in older adults, especially in the hippocampus (Plassman et al., 1996; Tohgi et al., 1997; den Heijer et al., 2002; Lemaitre et al., 2005; Lind et al., 2006; Wishart et al., 2006; Mueller et al., 2008), while others have not (Reiman et al., 1998; Bigler et al., 2003; Cherbuin et al., 2008). Even if volume differences do exists, it is not clear whether APOE has a direct effect on aging, or whether the differences are related to earlier developmental factors. Thinner entorhinal cortex has been found in young children and teenagers who 
were $\varepsilon 4$ carriers, indicating possible life-long influences of APOE on brain structure (Shaw et al., 2007). However, the effect size was small, and only barely statistically significant $(p=0.03$ ) with more than 530 scans analyzed. Based on cross-sectional data, Espeseth et al. (2008) found thicker cortex but steeper estimated decline in several areas in healthy middle-aged $\varepsilon 4$ carriers, indicating both developmental and age-related effects. In a follow-up study the same sample were tested with an attention task while ERPs were recorded. Increased thickness in cortical areas was associated with reduced ERP amplitudes, which in turn was associated with lower behavioral accuracy (Espeseth et al., 2010). These results indicate that $\varepsilon 4$ related increased cortical thickness in $\varepsilon 4$ carriers may be part of a dysfunctional process associated with advanced aging or $\mathrm{AD}$, or a compensatory response to such processes. Honea et al. (2009) recently used cross-sectional data to show reduced GM volume in $\varepsilon 4$ carriers, i.e. hippocampus and amygdala, as well as white matter diffusion (reduced fractional anisotropy, FA) in left parahippocampal gyrus. Still, opposite effects were also seen, e.g., in middle temporal and inferior frontal gyri. Thus, so far it seems that effects of APOE on brain volume in healthy elderly are modest, if existing at all, and to the degree that they are found, relationships appear stronger for the hippocampus than for e.g., whole-brain volume (Tohgi et al., 1997; den Heijer et al., 2002).

Some longitudinal studies have found greater rates of hippocampal atrophy in APOE $\varepsilon 4$ carriers compared to non-carriers in non-demented elderly (Cohen et al., 2001; Jak et al., 2007). Crivello et al. (2009) published the largest study to date on effects of APOE on brain aging, using a longitudinal cohort of 1,186 healthy elderly. Accelerated atrophy with increasing age was seen in the $\varepsilon 4$ homozygotes only, with no evidence for a dose effect. Thus, it is possible that longitudinal studies are capable of identifying subtle effects of APOE on brain structure that are hidden in cross-sectional studies. This was supported by Jak et al. (2007), where cross-sectional comparisons revealed no effect of APOE on hippocampal volume, while longitudinal atrophy was significantly greater for the participants with at least one APOE $\varepsilon 4$ allele.

There have been fewer studies addressing effects of APOE on WM characteristics, even though the function of APOE as involved in lipid transport indicates that effects on WM integrity may be as likely as effects on GM. Some studies have shown effects of APOE on diffusion properties of posterior corpus callosum and medial temporal lobe (Persson et al., 2006) and parahippocampal gyrus (Nierenberg et al., 2005) in healthy elderly. A recent study found higher correlations between corpus callosum volumes and age in $\varepsilon 4$-carriers than non-carriers (Filippini et al., 2009). Interestingly, the volume of the different ROIs was generally not different between the APOE groups, only the age-slope, indicating that APOE exerts its effects on white matter volume through life. Although not explicitly tested, the data seems to indicate an opposite relationship between APOE status and WM volume in the early $(\varepsilon 4>\varepsilon 3)$ versus the late $(\varepsilon 4<\varepsilon 3)$ phase of adult life. Future research will settle the issue of whether effects of APOE are larger on WM than on GM in aging, and longitudinal studies will be especially important.

\section{Effects of other candidate genes and brain aging}

Neurotrophins. Neurotrophins include nerve growth factor (NGF), BDNF, neurotrophin 3 (NT-3) and neurotrophin 4/5 (NT-4/5), and the most studied SNP of the BDNF gene is the Val66Met. One study found Met-BDNF carriers to show larger age-related reductions of prefrontal cortical volume (Nemoto et al., 2007) and amygdala volume (Sublette et al., 2008), and generally smaller hippocampal and prefrontal volumes independently of age (Pezawas et al., 2004). Differences in hippocampal volume between Val and Met carriers could be due to differences in dendritic complexity, fewer neuronal and supporting cells, and increased cell death or decreased neurogenesis during embryological development or over the life-span (Bath and Lee, 2006).

\section{Neuregulin 1: Of possible importance for the life-span trajectories} of WM changes is a specific variant of the Neuregulin 1 (NRG1) gene, associated with reduced white matter density and anisotropy (McIntosh et al., 2008). WM development is a very slow developmental process (Lebel et al., 2008), which makes genes regulating myelin possibly important for cognitive development and aging. Cellular studies have related NRG1 to myelination (Taveggia et al., 2008), and some diffusion tensor imaging (DTI) studies exist (McIntosh et al., 2008; Winterer et al., 2008; Konrad et al., 2009). NRG1 has also been related to RT measures in a attention task, which can be interpreted to mean that this gene is related to the capacity for fast transfer of information in the brain, probably though its effect on myelin (Konrad et al., 2009). Its role in brain aging is still mainly unknown.

Other genes of established or possible significance for cognitive functions are COMT, serotonergic genes, KIBRA, and GRM3 (glutamate receptor, metabotropic), but the significance of these genes for brain structure, or, more importantly, whether they modulate the relationship between changes in brain structure and changes in cognitive abilities in aging, is not known (Petrella et al., 2008).

In sum, there is to date relatively sparse evidence for effects of specific SNPs on brain aging. There may be several reasons for this. One may be that it is difficult to distinguish pure genetic influence from gene $\times$ environment interactions. Thus, factors such as nutrition, physical exercise, cognitive activity, etc. may affect brain morphometry and how the brain is influenced by aging, and individual differences in the level of these factors may be affected by genetic variations. Thus, the genetic influence on brain structure may partly be indirect through the influence on modulating factors. Second, different brain parameters may be related to different genes. For instance, a recent study found both cortical surface area (0.89) and thickness (0.81) to be highly heritable, but that they were essentially unrelated genetically (Panizzon et al., 2009). Thus, cortical volume, a typical measure in neuroimaging genetics, combines two distinct sources of genetic influences, and this may confound the underlying genetic architecture of brain structure. In line with this, a recent study found that common sequence variations in a region in and around MECP2 were associated with cortical surface area but not cortical thickness, specific to male gender and were related to only restricted cortical regions (cuneus, fusiform gyrus, pars triangularis) (Joyner et al., 2009). Most studies on the effects of specific SNPs on brain aging are cross-sectional, but due to large inter-individual variability, it is likely that SNPs affecting age-trajectories of different brain areas will be stronger predictors of brain change than brain differences. Some evidence for this is seen when effects of APOE are studied in cross-sectional versus longitudinal samples. 
Promising MR phenotypes in future studies would be cortical thickness and surface area measures, but not volume, since the latter probably confounds several sources of genetic influence. Further, DTI measures are very promising phenotypes, since the heritability of DTI is high and the development of WM is protracted through large parts of the adult life-span (Westlye et al., 2010). Of the commonly used DTI measures, however, fractional anisotropy (FA) is probably a less suitable candidate than the constituting diffusion eigenvectors (axial and radial diffusion), since it is likely that FA confounds distinct genetic influences.

\section{PROMISES AND CHALLENGES WITH GENOME-WIDE TECHNOLOGIES IN NEUROGENETIC STUDIES}

Although this article mainly focuses on neurogenetic data obtained from examination of single genes or only a few genes, the number of genes and SNPs that are included in association studies in general has undergone a tremendous increase over the last decade. Some years ago, technological and database developments made whole or genome-wide association studies (GWAS) a reality, making it possible to examine from 300,000 to more than one million SNPs over the whole genome, covering or tagging most human genes. The major advantage of this method is that it allows, in principle, for screening all genes in the genome for association to a particular disease or trait in a hypothesis free way, thereby permitting global genetic scanning and analysis of gene-gene interactions and pathway analysis, among other possibilities.

On the down side, the GWAS approach poses various challenges. The inherent massive number of statistical tests represents a huge risk for false-positive results, which is usually solved by implementing a very conservative threshold for genome-wide statistical significance around $p=10^{-8}$. In the range between $10^{-8}$ and nominal significance, there might be numerous highly interesting genetic determinants of the phenotype that are incorrectly assigned as nonsignificant in the ocean of false negative SNPs. It is also important to note that with increasingly heterogenous or "non-specific" phenotypes, gradually larger numbers of subjects are needed, with resulting high costs for GWAS studies.

An early and highly cited general example is the Wellcome Trust Case Control Consortium (WTCCC) that performed GWAS for coronary heart disease, hypertension, type 1 diabetes, type 2 diabetes, Crohn's disease, rheumatoid arthritis, and bipolar disorder (WTCCC, 2007). This study successfully uncovered many new susceptibility genes for most of the diseases in question, but the results on bipolar disorder were quite disappointing. There are now several published GWAS data and meta-analyses for other cognition-relevant neuropsychiatric diseases, such as AD, schizophrenia, and autism (e.g., Bertram and Tanzi, 2009; Harold et al., 2009; Purcell et al., 2009; Shi et al., 2009; Wang et al., 2009; Weiss et al., 2009). They have pointed at novel disease genes, all of small effect sizes. It is also worth noticing that GWAS data can be used to demonstrate shared genetic contribution across phenotypes, such as between schizophrenia and bipolar disorder, although the sobering tale is that the model fits better the larger the number of genes included (Purcell et al., 2009). This is interesting for cognition research, since the degree of genetic overlap between various inter-related cognitive parameters can be examined in a genomewide manner.
Still, there are so far few published data on genome wide studies of cognition. Butcher et al. (2008) examined a sample of 7,000 children who were tested for general cognitive ability $(g)$, using more than 500,000 SNPs in a two-stage approach. Six SNPs yielded nominally significant associations across the normal distribution of $g$, of which only one remained significant after correction with a false discovery rate of 0.05 . Interestingly, none of the SNPs accounted for more than $0.4 \%$ of the variance of $g$, in line with the expected polygenic nature of cognition. A recent, relatively small GWAS study $(N=514)$ of Digit Symbol (processing speed) and Stroop Color-Word (attention) performance found no genetic variants of large effect (Cirulli et al., in press). A larger study, which used over 350,000 SNPs and DNA pooling to test cognitive extremes in a sample of almost 8,000 children and followed up with individual genotyping in over 3000 , found no associations that survived multiple testing (Davis et al., in press). Their recommendations following these disappointing results were: use larger sample sizes, denser SNP arrays, and multiple replications. Since the estimated heritability of cognitive traits tend to increase with increasing age, it may be assumed that GWAS of older healthy individuals is more likely to further pinpoint the genetics of cognitive aging. The above-mentioned NCNG and LBC samples have all been subjected to genome-wide association studies, using Illumina microarrays (unpublished data).

Recently, it has been discovered that copy number variation (CNV) in the genome could be at least as important as SNPs for phenotypic variation among subjects in the population, involving both gain (duplication) and loss (deletion) of genomic material. Such CNVs have been associated with neurogenetic diseases as schizophrenia and autism (Sebat et al., 2007; Stefansson et al., 2008), and a specific CNV may predispose for several phenotypes, such as the 16p11.2 microdeletion that implies markedly increased risk for autism, mental retardation, schizophrenia and even severe obesity (Kumar et al., 2008; Weiss et al., 2008; Bijlsma et al., 2009; McCarthy et al., 2009; Merikangas et al., 2009). Genome-wide CNV information can be extracted from the GWAS SNP data. It is therefore timely to explore relevant data sets for the potential role of copy number variation for cognitive functioning in older adults.

The newest wave of high-throughput genomics is represented by massively parallel sequencing technology, also named "deep sequencing", which aims at producing the complete DNA sequence of larger selected parts (e.g., targeted resequencing or exome sequencing) or the whole genome from single subjects (for review, see Metzker, 2010). Although the costs of such methods are still substantial (but rapidly declining), it is thus possible to obtain information about almost all genomic variants in a certain individual, including SNPs, CNVs, and more complex rearrangements. This approach has already disclosed a surprisingly high level of private DNA variants, in addition to millions of more common well known SNPs and CNVs, and new disease genes with monogenic inheritance are being identified (Ng et al., 2010). The relevance of deep sequencing studies for cognitive genetics remains to be seen.

\section{SUMMING UP THE STATUS OF NEUROGENETIC STUDIES}

The approaches documented above show that although each have limitations and problems, there is convergent information that individual variation in genes central to maintaining synaptic 
integrity, neurotransmitter function, and synaptic plasticity are important in affecting age-related changes in brain structure and cognition. Studies of cognitive phenotypes may be advanced by clarification of contributions from general versus domain-related phenotypes and from closer integration of phenotypes with neurobiological mechanisms across animal and human studies. Selection of genotypes for further studies also warrants critical scrutiny. An exclusive focus on isolated SNPs disregard the complexity of variations within single genes, where a haplotype or whole-gene-based approach may have a greater likelihood of attaining reproducible results. Biological and genetic information on expression in brain tissue and regional brain differences may be used to a larger extent in selecting genes of interest, including information on age-related differences. Since the majority of studies so far suffer from limited number of participants, and it is not likely that really large scales samples including very comprehensive information will become available in the foreseeable future although, replication across existing samples is a viable intermediate term strategy.

\section{IMPLICATIONS FOR COGNITIVE AGING AND INTERVENTION}

Neurogenetic studies of cognitive aging offer the promise of improving our understanding of how various experiential and life style factors may help limit cognitive decline in older adults. As evidence of the older brain's plasticity mounts (Cotman and Berchtold, 2002; Burke and Barnes, 2006), activities such as aerobic exercise, engagement in cognitively stimulating tasks, etc. have been found to reduce cognitive decline in older adults (Kramer et al., 1999; Hillman et al., 2006; Mahncke et al., 2006; Hertzog et al., 2009). While, on average, older individuals may benefit from such preventative efforts, some may benefit more, while others may not. Given the evidence for APOE as a major risk gene for dementia and for age-related cognitive decline, interventions targeted to carriers of the $\varepsilon 4$ allele are of primary interest. Carriers of $\varepsilon 4$ constitute $20-40 \%$ of the population in the western world and have about a risk of receiving a diagnosis of Alzheimer's disease 2-8 year earlier, depending on $\varepsilon 4$ dose (Raber et al., 2004, Table 4). Interventions that could delay onset of dementia by even months would have a significant impact on quality of life and health costs.

As an example of an intervention or life style factor, consider aerobic exercise. The beneficial effects of exercise may vary with APOE genotype. In a recent randomized clinical trial study, Lautenschlager et al. (2008) assigned older adults (mean age 68) with self-reported memory problems (but not meeting criteria for dementia) to either a 6-month home-based program of physical activity or a "usual care" program. Among those who participated in physical activity, general cognitive function was higher in those without the APOE- $\varepsilon 4$ allele than in $\varepsilon 4$ carriers. Epidemiological studies (Kivipelto et al., 2008) also find that midlife physical activity has a positive effect on dementia risk, and more so in APOE $\varepsilon 4$ carriers.

The Lautenschlager et al. (2008) results are interesting and of value because of the use of a randomized trial design, which is rare in studies on examining factors that may influence or limit age-related cognitive decline (Hertzog et al., 2009). However, the dependent measure used in this study was a relatively crude index of cognition, the Alzheimer's Disease Assessment Scale (ADAS), and it would be of interest to conduct additional studies in which the psychometric, cognitive neuroscience, or structural brain imaging measures described in this paper were used in studies of exercise or other interventions.

Further knowledge regarding the mechanisms of interactions between genotype and preventative factors will help in understanding how the ameliorative effect of various experiential and lifestyle factors on age-related cognitive decline differ between individuals. Animal studies (Berchtold et al., 2010) indicate that the beneficial effect of exercise on cognition may be mediated by BDNF, indicating that further studies in humans are important.

Cognition enhancing drugs may also have genotype dependent effects. Marchand et al. (2010) found that APOE $\varepsilon 4$ carriers showed a greater cognitive benefit from nicotinic stimulation than did non-carriers. These results are interesting in view of the interaction between APOE and cholinergic receptor genes cited previously (Espeseth et al., 2006; Parasuraman and Espeseth, 2007; Reinvang et al., 2010b). Raber et al. (2002) found that androgens protect against APOE-related cognitive decline in rodents. Burkhardt et al. (2006) found an interaction between testosterone levels and APOE in healthy cognitively normal males. For tests of executive functions, but not for tests of episodic memory, $\varepsilon 4$ carriers with high testosterone levels performed worse than $\varepsilon 4$ carriers with low testosterone levels, cautioning that androgen supplementation may not be beneficial for this group.

Park and Reuter-Lorenz (2009) suggest that frontal lobe functions form an important substrate for the scaffolding mechanisms believed to support normal function in the face of neurological damage and deterioration. That should imply that functions subsumed under cognitive control and executive attention would be good targets for preventive intervention with a view to promote adaptive function. Data from the present authors and others indicate that there are replicable findings of influence by neurotransmission genes on executive attention (Greenwood et al., 2005b; Parasuraman et al., 2005; Espeseth et al., 2006), reasoning (Harris et al., 2006), and working memory (Parasuraman et al., 2005; Greenwood et al., 2009b; Reinvang et al., 2009). The work of Kramer and colleagues (Colcombe and Kramer, 2003; Colcombe et al., 2004; Hillman et al., 2006) has indeed found that the benefits of aerobic exercise on cognitive functioning and in older adults are greatest for frontal-cortex mediated functions such as executive control and working memory. Accordingly, it would be of interest to examine whether individual differences in the degree of benefit conferred by exercise and other preventative treatments can be parsed by neurotransmission genes that influence frontal lobe function. Neurotrophic and neuronal repair genes such as BDNF and APOE may play a similar moderating role.

Reduced hippocampal activation in concert with increased frontal activation is seen in studies of older participants with normal memory functions. Memory impairment with changes in hippocampal activation or reduction in hippocampal volume is indicative of pathological factors affecting cognitive aging negatively. Preventive intervention would have a focus on slowing or preventing deterioration or limiting the influence of a pathognomonic agent. Data from the present authors and others indicate that there are replicable findings of influence by neurotrophic genes (BDNF) on episodic memory (Le Hellard et al., 2009) as well as of APOE. 


\section{CONCLUSIONS AND DIRECTIONS FOR FUTURE RESEARCH}

There is considerable interest in understanding how certain experiential and lifestyle factors may reduce or even arrest age-related cognitive decline (Hertzog et al., 2009). A better understanding of genetic influences on cognitive aging can help in choosing interventions for further analysis and study. There are as yet only a few studies examining interactions between specific genotypes and intervention or treatment factors, particularly those that use randomized control designs. The multiple-phenotype approach advocated in this article, based on psychometric, cognitive neuroscience, and brain morphometric measures, can inform the design of more such studies.

We believe that the methods we have outlined in this article can be combined with other complementary strategies. For example, it may be useful to link the multiple-phenotype approach we have proposed for the cognitive neurogenetics of aging with genetic investigations focused more directly on molecular pathways involved in brain aging (Yankner et al., 2008). The use of gene expression arrays across a range of species has lead to the identification of several evolutionary conserved mechanisms of brain aging. Clusters of genes associated with longevity and brain function in animal models on aging have been found to be either up-regulated (e.g., genes related to stress response such as antioxidants and DNA repair, inflammation, lipid

\section{REFERENCES}

Alkondon, M., Pereira, E. F., Eisenberg, H. M., and Albuquerque, E. X. (2000). Nicotinic receptor activation in human cerebral cortical interneurons: a mechanism for inhibition and disinhibition of neuronal networks. J. Neurosci. 20, 66-75.

Almasy, L., Porjesz, B., Blangero, J., Goate, A., Edenberg, H. J., Chorlian, D. B., Kuperman, S., O'Connor, S. J., Rohrbaugh, J., Bauer, L. O., Foroud, T., Rice, J. P., Reich, T., and Begleiter, H. (2001). Genetics of event-related brain potentials in response to a semantic priming paradigm in families with a history of alcoholism. Am. J. Hum. Genet. 68, 128-135.

Barnett, J. H., Scoriels, L., and Munafò, M. R. (2008). Meta-analysis of the cognitive effects of the catechol-Omethyltransferase gene Val158/108Met polymorphism. Biol. Psychiatry 64, 137-144.

Bartzokis, G., Lu, P. H., Geschwind, D. H., Tingus, K., Huang, D., Mendez, M. F., Edwards, N., and Mintz, J. (2007). Apolipoprotein E affects both myelin breakdown and cognition: implications for age-related trajectories of decline into dementia. Biol. Psychiatry $62,1380-1387$

Bath, K. G., and Lee, F. S. (2006). Variant BDNF (Val66Met) impact on brain structure and function. Cogn. Affect. Behav. Neurosci. 6, 79-85.

Berchtold, N. C., Castello, N., and Cotman, C. W. (2010). Exercise and

metabolism) or down-regulated (neural plasticity and synaptic function, mitochondrial function, insulin signaling) also in normal human aging (Lu et al., 2004; Fraser et al., 2005; Loerch et al., 2008; Flachsbart et al., 2009; Suh et al., 2009). In addition, caloric restriction, a procedure that modulates the expression level of genes related to longevity (e.g., sirtuins), has been shown to improve learning and memory by up to $20 \%$ in older humans (Witte et al., 2009). Thus, SNPs or structural variants in genes related to mechanisms of brain aging could be associated with either accelerated or stable aging trajectories and can serve as markers for association studies where gene by age interactions are modeled across multiple phenotypes.

The multiple-phenotype approach to the cognitive neurogenetics of aging is one clear recommendation of our review of the literature. We propose that future studies should follow this approach, because it permits an understanding of the neural impact of genetic variants that may contribute to differential patterns of cognitive aging. We provided several exemplars of what such research can look like, and while it is true that as of yet no well-replicated genes linked to cognitive aging have been identified (apart from APOE), we believe the multiple-phenotype approach, coupled with judicious application of the newer, more powerful genetic tools, can yield new insights into genetic influences on the course of cognitive aging.

autism and in normal individuals. Eur. J. Med. Genet. 52, 77-87.

Bilder, R. M., Sabb, F. W., Cannon, T. D., London, E. D., Jentsch, J. D., Parkerd, D. S., Poldrack, R. A., Evans, C., and Freimera, R. (2009). Phenomics: the systematic study of phenotypes on a genome-wide scale. Neuroscience 164 30-42.

Braak, H., and Braak, E. (1995). Staging of Alzheimer's disease-related neurofibrillary changes. Neurobiol. Aging 16, 271-284.

Buckner, R. L. (2004). Memory and executive function in aging and AD. Neuron 55, 195-208.

Butcher, L. M., Davis, O. S., Craig, I. W., and Plomin, R. (2008). Genome-wide quantitative trait locus association scan of general cognitive ability using pooled DNA and 500K single nucleotide polymorphism microarrays Genes Brain Behav. 7, 435-446.

Burke, S. A., and Barnes, C. A. (2006). Neural plasticity in the ageing brain. Nat. Rev. Neurosci. 7, 30-40.

Burkhardt, M. S., Foster, J. K., Clarnette, R. M., Chubb, S. A., Bruce, D. G., Drummond, P. D., Martins, R. N., and Yeap, B. B. (2006). Interaction between testosterone and apolipoprotein E epsilon4 status on cognition in healthy older men. J. Clin. Endocrinol. Metab. 91, 1168-1172.

Cherbuin, N., Anstey, K. J., Sachdev, P. S., Maller, J. J., Meslin, C., Mack, H. A., Wen, W., and Easteal, S. (2008). Total and regional gray matter volume is not related to $\mathrm{APOE}^{\star} \mathrm{E} 4$ status in a community sample of middle-aged individuals. J. Gerontol. A Biol. Sci. Med. Sci. 63, 501-504.

Chiang, M. C., Barysheva, M., Shattuck, D. W., Lee, A. D., Madsen, S. K. Avedissian, C., Klunder, A. D, Toga, A. W., McMahon, K. L., de Zubicaray, G. I., Wright, M. J., Srivastava, A., Balov, N., and Thompson, P. M. (2009). Genetics of brain fiber architecture and intellectual performance. J. Neurosci. 29, 2212-2224.

Cirulli, E. T., Kasperaviciute, D., Attix, D. K., Need, A. C., Ge, D., Gibson, G., and Goldstein, D. B. (in press). Common genetic variation, and performance on standardized cognitive tests. Eur. J. Hum. Genet. doi: 10.(1038)/ejhg.2010.2.

Cohen, R. M., Small, C., Lalonde, F., Friz, J., and Sunderland, T. (2001). Effect of apolipoprotein E genotype on hippocampal volume loss in aging healthy women. Neurology 57, 2223-2228.

Colcombe, S., and Kramer, A. F. (2003). Fitness effects on the cognitive function of older adults: a meta-analytic study. Psychol. Sci. 14, 125-130.

Colcombe, S. J., Kramer, A. F., Erickson, K. I., Scalf, P., McAuley, E., Cohen, N. J., Webb, A., Jerome, G. J., Marquez, D. X., and Elavsky, S. (2004). Cardiovascular fitness, cortical plasticity, and aging. Proc. Natl. Acad. Sci. U.S.A. 101, 3316-3321.

Corbetta, M., Kincade, J. M., Ollinger, J. M., McAvoy, M. P., and Shulman, G. 
L. (2000). Voluntary attention is dissociated from target detection in the human posterior parietal cortex. Nat. Neurosci. 3, 292-297.

Corbetta, M., Shulman, G. L., Miezin, F. M., and Petersen, S.E. (1995). Superior parietal cortex activation during spatial attention shifts and visual feature conjunction. Science 270, 802-805.

Corder,E.H., Saunders, A.M., Strittmatter, W. J., Schmechel, D. E., Gaskell, P. C., Small, G. W., Roses, A. D., Haines, J. L., Pericak-Vance, M. A. (1993). Gene dose of apolipoprotein E type 4 allele and the risk of Alzheimer's disease in late onset families. Science 261, 921-923.

Cotman, C. W., and Berchtold, N. C. (2002). Exercise: a behavioral intervention to enhance brain health and plasticity. Trends Neurosci. 25, 295-301.

Court, J. A., Lloyd, S., Johnson, M., Griffiths, M., Birdsall, N. J., Piggott, M. A., Oakley, A. E., Ince, P. G., Perry, E. K., and Perry, R.H. (1997). Nicotinic and muscarinic cholinergic receptor binding in the human hippocampal formation during development and aging. Dev. Brain Res. 101, 93-105.

Crivello, F., Lemaitre, H., Dufouil, C., Grassiot, B., Delcroix, N., TzourioMazoyer, N., Tzourio, C., and Mazoyer, B. (2009). Effects of ApoE-epsilon4 allele load and age on the rates of grey matter and hippocampal volumes loss in a longitudinal cohort of 1,186 healthy elderly persons. Neuroimage 47, Supplement 1, S173.

Davis, O. S. P., Butcher, L. M., Docherty, S. J., Meaburn, E. L., Curtis, C. J. C., Simpson, M. A., Schalkwyk, L. C., and Plomin, R. (in press). A threestage genome-wide association study of general cognitive ability: hunting the small effects. Behav. Genet. doi: 10.(1007)/s10519-010-9350-4.

Deary,I.J.(2000).Looking Downon Human Intelligence: From Psychometrics to the Brain. London: Oxford University Press.

Deary, I. J., Corley, J., Gow, A. J., Harris, S. E., Houlihan, L. M., Marioni, R. E., Penke, L., Rafnsson, S. B., and Starr, J. M. (2009a). Age-associated cognitive decline. Br. Med. Bull. 92, 135-152.

Deary, I. J., Johnson, W., and Houlihan, L. M. (2009b). Genetic foundations of human intelligence. Hum. Genet. 216, 215-232.

Deary, I. J., Gow, A. J., Taylor, M.D., Corley, J., Brett, C., Wilson, V., Campbell, H., Whalley, L. J., Visscher, P. M., Porteous, D. J., and Starr, J. M. (2007). The Lothian Birth Cohort 1936: a study to examine influences on cognitive ageing from age 11 to age 70 and beyond. BMC Geriatr. 7,28. doi: 10.1186/14712318-7-28.
Deary, I. J., Penke, L., and Johnson, W. (2010). The neuroscience of human intelligence differences. Nat. Rev. Neurosci. 11, 201-211.

Deary, I. J., Spinath, F. M., and Bates, T. C. (2006). Genetics of intelligence. Eur. J. Hum. Genet. 14, 690-700.

Deary, I. J., Whiteman, M. C., Pattie, A., Starr, J. M., Hayward, C., Wright, A. F., Carothers, A., and Whalley, L. J. (2002). Cognitive change, and the APOE $\varepsilon 4$ allele. Nature 418, 932.

den Heijer, T., Oudkerk, M., Launer, L. J., van Duijn, C. M., Hofman, A., and Breteler, M. M. (2002). Hippocampal, amygdalar, and global brain atrophy in different apolipoprotein E genotypes. Neurology 59, 746-748.

Egan, M. F., Kojima, M., Callicott, J. H., Goldberg, T. E., Kolachana, B. S., Bertolino, A., Zaitsev, E., Gold, B., Goldman, D., Dean, M., Lu, B., and Weinberger, D. R. (2003). The BDNF val66met polymorphism affects activity-dependent secretion of BDNF and human memory and hippocampal function. Cell 112, 257-269.

Espeseth, T., Endestad, T., Rootwelt, H., and Reinvang, I. (2007). Nicotine receptor gene CHRNA4 modulates early event-related potentials in auditory and visual oddball target detection tasks. Neuroscience 147, 974-985.

Espeseth, T. Greenwood, P. M., Reivang, I., Fjell, A. M., Walvhold, K. B., Westlye, E., Lundervold, A., Rootvelt, H., and Parasuraman, R. (2006). Interactive effects of APOE and CHRNA4 on attention and white matter volume in healthy middle-aged and older adults. Cogn. Affect. Behav. Neurosci. 6, 31-43.

Espeseth, T., Westlye, L. T., Fjell, A. M., Walhovd, K. B., Rootwelt, H., and Reinvang, I. (2008). Accelerated agerelated cortical thinning in healthy carriers of apolipoprotein E epsilon 4. Neurobiol. Aging 29, 329-340.

Espeseth, T., Westlye, L. T., Walhovd, K. B., and Fjell,. A. M., Endestad, T., Rootwelt, H., and Reinvang, I. (2010). Apolipoprotein E-related thickening of the cerebral cortex modulates selective attention. Neurobiol. Aging doi: 10.1016/j. neurobiolaging.2009.12.027.

Everitt, B. J., and Robbins, R. (1997). Central cholinergic systems and cognition. Annu. Rev. Psychol. 48, 649-684.

Fan, J., Fossella, J. A., Sommer, T., Wu, Y., and Posner, M. I. (2003). Mapping the genetic variation of attention onto brain activity. Proc. Natl. Acad. Sci. U.S.A. 100, 7406-7411.

Fan, J., McCandliss, B. D., Fossella, J., Flombaum, J. I., and Posner, M. I.
(2005). The activation of attentional networks. Neuroimage 26, 471-479.

Fan, J., Wu, Y., Fossella, J., and Posner, M. I. (2001). Assessing the heritability of attention networks. BMC Neurosci. 2:14, 14-19.

Filippini, N., Zarei, M., Beckmann, C. F., Galluzzi,S., Borsci, G., Testa, C., Bonetti, M.,Beltramello,A., Ghidoni, R., Benussi, L., Binetti, G., and Frisoni, G. B. (2009) Regional atrophy of transcallosal prefrontal connections in cognitively normal APOE epsilon4 carriers. J. Magn. Reson. Imaging 29, 1021-1026.

Flachsbart, F., Caliebe, A., Kleindorp, R., Blanché, H., von Eller-Eberstein, H., Nikolaus, S., Schreiber, S., and Nebel, A. (2009). Association of FOXO3A variation with human longevity confirmed in German centenarians. Proc. Natl. Acad. Sci. U.S.A. 106 2700-2705.

Flores, C. M., DeCamp, R. M., Kilo, S. Rogers, S. W., and Hargreaves, K. M. (1996). Neuronal nicotinic receptor expression in sensory neurons of the rat trigeminal ganglion: demonstration of alpha3beta4, a novel subtype in the mammalian nervous system. $J$. Neurosci. 16, 7892-7901.

Fodor, J. (1983). The Modularity of Mind. Cambrige, MA: MIT Press.

Fossella, J., Sommer, T., Fan, J., Wu, Y., Swanson, J.M., Pfaff, D. W., and Posner M. I. (2002). Assessing the molecular genetics of attention networks. BMC Neurosci. 3, 14-19.

Fraser, H. B., Khaitovich, P., Plotkin, J. B., Pääbo, S., and Eisen, M. B. (2005) Aging and gene expression in the primate brain. PLoS Biol. 9:e274. doi 10.1371/journal.pbio.0030274.

Goldberg, T. E., and Weinberger, D. R. (2004). Genes and the parsing of cognitive processes. Trends in Cogn. Sci. 8, 325-335.

Goldman,D., Weinberger, D. R., Malhotra, A. K., and Goldberg, T. E. (2009). The role of COMT Val158Met in cognition. Biol. Psychiatry 65, 1-2.

Gooney, M., Messaoudi, M., Maher, F O., Bramham, C., and Lynch, M. A (2004). BDNF-induced LTP in dentate gyrus is impaired with age: analysis of changes in cell signaling events. Neurobiol. Aging 25, 1323-1331.

Green, A., Munafo, M., DeYoung, C. Fossella, J., and Gray, J. (2008). Using genetic data in cognitive neuroscience: from growing pains togenuineinsights. Nat. Rev. Neurosci. 9, 710-720.

Greenwood, P., and Parasuraman, R. (2003). Normal genetic variation, cognition, and aging. Behav. Cogn Neurosci. Rev. 2, 278-306.

Greenwood, P. M. (2007). Functional plasticity in cognitive aging: review and hypothesis. Neuropsychology 21 , 657-673.
Greenwood, P. M., Fossella, J., and Parasuraman, R. (2005a). Specificity of the effect of a nicotinic receptor polymorphism on individual differences in visuospatial attention. J. Cogn. Neurosci. 17, 1611-1620.

Greenwood, P., Lambert, C., Sunderland, T., and Parasuraman, R. (2005b). Effects of Apolipoprotein E genotype on spatial attention, working memory, and their interaction in healthy, middle-aged adults: results from the National Institute of Mental Health's BIOCARD Study. Neuropsychology 19, 199-211.

Greenwood, P. M., Sunderland, T., Putnam, K., Levy, J., and Parasuraman, R. (2005c). Scaling of visuospatial attention undergoes differential longitudinal change as a function of APOE genotype prior to old age: results from the National Institute of Mental Health's BIOCARD study. Neuropsychology 19, 830-840.

Greenwood, P. M., Lin, M.-K., Sundararajan, R., Fryxell, K. J., and Parasuraman, R. (2009a). Synergistic effects of genetic variation in nicotinic and muscarinic receptors on visual attention but not working memory. Proc. Natl. Acad. Sci. U.S.A. 106, 3633-3638.

Greenwood, P. M., Sundararajan, R., Lin, M.-K., Fryxell, K. J., and Parasuraman, R. (2009b). Both a nicotinic single nucleotide polymorphism (SNP) and a noradrenergic SNP modulate working memory performance when attention is manipulated. J. Cogn. Neurosci. $21,2139-2153$.

Greenwood, P. M., Sunderland, T., Friz, J. L., and Parasuraman, R. (2000). Genetics and visual attention: selective deficits in healthy adult carriers of the varepsilon 4 allele of the apolipoprotein Egene. Proc. Natl. Acad. Sci. U.S.A. 97, 11661-11666.

Gureje, O., Ogunniyi, A., Baiyewu, O., Price, B., Unverzagt, F. W., Evans, R. M., Smith-Gamble, V., Lane, K. A., Gao, S., Hall, K. S., Hendrie, H. C., and Murrell, J. R. (2006). APOE epsilon4 is not associated with Alzheimer's disease in elderly Nigerians. Ann. Neurol. 59, 182-185.

Hariri, A. R., Goldberg, T. E., Mattay, V. S., Kolachana, B. S., Callicott, J. H., Egan, M. F., and Weinberger, D. R. (2003). Brain-derived neurotrophic factor val66met polymorphism affects human memory-related hippocampal activity and predicts memory performance. J. Neurosci. 23, 6690-6694.

Harold, D., Abraham, R., Hollingworth, P., Sims, R., Gerrish, A., Harold, D., Abraham, R., Hollingworth, P., Sims, R., Gerrish, A., Hamshere, M. L., Pahwa, J.S., Moskvina, V., Dowzell, K., Williams, A., Jones, N., Thomas, C., 
Stretton, A., Morgan, A. R., Lovestone, S., Powell, J. , Proitsi, P., Lupton, M. K., Brayne, C., Rubinsztein, D. C., Gill, M., Lawlor, B., Lynch, A., Morgan, K., Brown, K. S., Passmore, P. A., Craig, D., McGuinness, B., Todd, S., Holmes, C., Mann, D., Smith, A. D., Love, S., Kehoe, P. G., Hardy, J., Mead, S., Fox, N., Rossor, M., Collinge, J., Maier, W., Jessen, F., Schürmann, B., van den Bussche, H., Heuser, I., Kornhuber, J., Wiltfang, J., Dichgans, M., Frölich, L., Hampel, H., Hüll, M., Rujescu, D., Goate, A. M., Kauwe, J.S. K., Cruchaga, C., Nowotny, P., Morris, J. C., Mayo, K., Sleegers, K., Bettens, K., Engelborghs, S., De Deyn, P. P., Van Broeckhoven, C., Livingston, G., Bass, N. J., Gurling, H., McQuillin, A., Gwilliam, R., Deloukas, P., Al-Chalabi, A., Shaw, C. E., Tsolaki, M., Singleton, A. B., Guerreiro, R., Mühleisen, T. W., Nöthen, M. M., Moebus, S., Jöckel, K.-H., Klopp, N., Wichmann, H.-E., Carrasquillo, M. M., Pankratz, V. S., Younkin, S. G., Holmans, P. A., O’Donovan, M., Owen, M. J., and Williams, J.(2009). Genome-wide association study identifies variants at CLU and PICALM associated with Alzheimer's disease. Nat. Genet. 41, 1088-1093. Erratum in: Nat. Genet. 41, 1156

Harris, S. E., Fox, H., Wright, A. F., Hayward, C., Starr, J. M., Whalley, L. J., and Deary, I. J. (2006). The brainderived neurotrophic factor Val66Met polymorphism is associated with agerelated change in reasoning skills. Mol. Psychiatry 11, 505-513.

Harris, S. E., Wright, A. F., Hayward, C. Starr, J. M., Whalley, L. J., and Deary, I. J. (2005). The functional COMT polymorphism, Val158Met, is associated with Logical Memory and the personality trait intelligence/imagination in a cohort of healthy 79 year olds. Neurosci. Lett. 385, 1-6.

Hertzog, C., Kramer, A. F., Wilson, R. S., and Lindenberger, U. (2009). Enrichment effects on adult cognitive development: can the functional capacity of older adults be preserved and enhanced? Psychol. Sci. Public Interest 8, 1-65.

Hillman, C. H., Erikson, K. I., and Kramer, A. F. (2006). Be smart, exercise your heart: exercise effects on brain and cognition. Nat. Rev. Neurosci. 9, 59-65.

Honea, R. A., Vidoni, E., Harsha, A., and Burns, J. M. (2009). Impact of APOE on the healthy aging brain: a voxel-based MRI and DTI study. J. Alzheimers Dis. 18, 564-663.

Houlihan, L. M., Harris, S. E., Luciano, M., Gow, A. J., Starr, J. M., Visscher, P. M., and Deary, I. J. (2009). Replication study of candidate genes for cognitive abilities: the Lothian Birth Cohort 1936. Genes Brain Behav. 8 , 238-247.

Ioannidis, J. P., Ntzani, E. E., Trikalinos, T. A., and Contopoulos-Ioannidis, D. G. (2001). Replication validity of genetic association studies. Nat. Genet. 29, 306-309.

Jak, A. J., Houston, W. S., Nagel, B. J., Corey-Bloom, J., and Bondi, M. W. (2007). Differential cross-sectional and longitudinal impact of APOE genotype on hippocampal volumes in nondemented older adults. Dement. Geriatr. Cogn. Disord. 23, 382-389.

Joyner, A. H., Roddey, J. C., Bloss, C. S., Bakken, T. E., Rimol, L. M., Melle, I., Agartz, I., Djurovic, S., Topol, E. J., Schork, NJ, Andreassen OA, and Dale AM. (2009). A common MECP2 haplotype associates with reduced cortical surface area in humans in two independent populations. Proc. Natl. Acad. Sci. U.S.A. 106, 15483-15488.

Khaitovich, P., Weiss, G., Lachmann, M., Hellmann, I., Enard, W., Muetzel, B., Wirkner, U., Ansorge, W., and Paabo S. (2004). A neutral model of transcriptome evolution. PLoS Biology 2, 682-689.

Kivipelto, M., Rovio, S., Ngandu, T., Kåreholt, I., Eskelinen, M., Winblad, B., Hachinski, V., Cedazo-Minguez, A., Soininen, H., Tuomilehto, J., and Nissinen, A. (2008). Apolipoprotein E epsilon4 magnifies lifestyle risks for dementia: a population-based study. J. Cell. Mol. Med. 12, 2762-2771.

Konrad, A., Vucurevic, G., Musso, F., Stoeter, P., Dahmen, N., and Winterer, G. (2009). ErbB4 genotype predicts left frontotemporal structural connectivity in human brain. Neuropsychopharmacology 34, 641-650.

Kramer, A. F., Bherer, L., Colcombe, S. J., Dong, W., and Greenough, W. T. (2004). Environmental influences on cognitive and brain plasticity during aging. J. Gerontol. A 59, M940-M957.

Kramer, A. F., Hahn, S., Cohen, N. J., Banich, M. T., McAuley, E., Harrison, C. R., Chason, J., Vakil, E., Bardell, L., Boileau, R. A., and Colcombe, A. (1999). Ageing, fitness and neurocognitive function. Nature 400 418-419.

Kumar, R. A, Mohamed, S. K., Sudi, J., Conrad, D. F., Brune, C., Badner, J. A., Gilliam, T. C., Nowak, N. J., Cook, E. H., Dobyns, W. B., and Christian, S. L. (2008). Recurrent 16p11.2 microdeletions in autism. Hum. Mol. Genet. 17, 628-638.

Lautenschlager, N. T., Cox, K. L., Flicker, L., Foster, J. K., van Bockxmeer, F. M. Xiao, J., Greenop, K. R., and Almeida,
O. P. (2008). Effect of physical activity on cognitive function in older adults at risk for Alzheimer Disease: a randomized trial. J. Am. Med. Assoc. 300 , 1027-1037.

Lebel, C., Walker, L., Leemans, A., Phillips, L., and Beaulieu, C. (2008). Microstructural maturation of the human brain from childhood to adulthood. Neuroimage 40 1044-1055.

Le Hellard, S., Håvik, B., Espeseth, T., Breilid, H., Løvlie, R., Luciano, M., Gow, A. J., Harris, S. E., Starr J. M., Wibrand, K., Lundervold, A. J., Porteous, D. J., Bramham, C. R. Deary, I. J., Reinvang, I., and Steen, V. M. (2009). Variants in doublecortinand calmodulin kinase like 1, a gene up-regulated by BDNF, are associated with memory and general cognitive abilities. PLoS ONE, 4, e7534.

Lemaitre, H., Crivello, F., Dufouil, C. Grassiot, B., Tzourio, C., Alperovitch, A., and Mazoyer, B. (2005). No epsilon4 gene dose effect on hippocampal atrophy in a large MRI database of healthy elderly subjects. Neuroimage 24, 1205-1213.

Levin, E. D., and Simon, B. B. (1998) Nicotinic acetylcholine involvement in cognitive function in animals. Psychopharmacology (Berl.) 13, 217-230.

Lind, J., Larsson, A., Persson, J., Ingvar, M., Nilsson, L. G., Bäckman, L. Adolfsson, R., Cruts, M., Sleegers, K. Van Broeckhoven, C., and Nyberg, L. (2006). Reduced hippocampal volume in non-demented carriers of the apolipoprotein E epsilon4: relation to chronological age and recognition memory. Neurosci. Lett. 396, 23-27.

Lindenberger, U., Nagel, I. E., Chicherio, C., Li, S. C., Heekeren, H. R., and Bäckman, L. (2008). Age-related decline in brain resources modulates genetic effects on cognitive functioning. Front. Neurosci. 2, 234-244. doi: 10.3389/neuro.01.039.2008.

Loerch, P. M., Lu, T., Dakin, K. A., Vann, J. M., Isaacs, A., Geula, C., Wang, J., Pan, Y., Gabuzda, D. H., Li, C., Prolla, T. A. and Yankner, B. A. (2008). Evolution of the aging brain transcriptome and synaptic regulation. PLoS One 3:e3329. doi: 10.1371/journal. pone.0003329.

Lu, T., Pan, Y., Kao, S. Y., Li, C., Kohane, I., Chan, J., andYankner BA. (2004). Gene regulation and DNA damage in the ageing human brain. Nature 429 , 883-891.

Luciano, M., Gow, A. J., Taylor, M. D., Hayward, C., Harris, S. E., Campbell, H., Porteous, D. J., Starr, J. M. Visscher.P.M., and Deary, I.J. (2009a). Apolipoprotein $\mathrm{E}$ is not related to memory abilities at 70 years of age Behav. Genet. 39, 6-14.

Luciano, M., Gow, A. J., Harris, S. E., Hayward, C., and Allerhand, M. (2009b). Cognitive ability at age 11 and 70 years, information processing speed, and APOE variation: the Lothian Birth Cohort 1936 study. Psychol. Aging 24, 129-138.

Mahley, R. W., Weisgraber, K. H., and Huang, Y. (2006). Apolipoprotein E4: a causative factor and therapeutic target in neuropathology, including Alzheimer's disease. Proc. Natl. Acad. Sci. U.S.A. 103, 5644-5651.

Mahncke, H. W., Connor, B. B., Appelman, J., Ahsanuddin, O. N., Hardy, J. L., Wood, R. A., Joyce, N. M., Boniske, T., Atkins, S. M., and Merzenich, M. M. (2006). Memory enhancement in healthy older adults using a brain plasticity-based training program: a randomized, controlled study. Proc. Natl. Acad. Sci. U.S.A. 103, 12523-12528.

Marchant, N. L., King, S. L., Tabet, N. and Rusted, J. M. (2010). Positive effects of cholinergic stimulation favor young APOE epsilon4 carriers. Neuropsychopharmacology 35, 1090-1096.

Martin-Ruiz, C. M., Court, J. A., Molnar, E., Lee, M., Gotti, C., Mamalaki, A. Tsouloufis, T., Tzartos, S., Ballard, C., Perry, R. H., and Perry, E. K. (1999). Alpha4 but not alpha3 and alpha7 nicotinic acetylcholine receptor subunits are lost from the temporal cortex in Alzheimer's disease. J. Neurochem. 73, 1635-1640.

McCarthy, S. E., Makarov, V., Kirov, G., Addington, A. M., and McClellan, J. (2009). Microduplications of 16p11.2 are associated with schizophrenia. Nat. Genet. 41, 1223-1227.

McClearn, G. E., Johansson, B., Berg, S., Pedersen, N. L., Ahern, F., Petrill, S. A., and Plomin, R. (1997). Substantial genetic influence on cognitive abilities in twins 80 or more years olf. Science 276, 1560-1563.

McIntosh, A. M., Moorhead, T. W., Job, D., Lymer, G. K., Maniega, S. M., McKirdy, J., Sussmann, J. E. D., Baig, B. J., Bastin, M. E., Porteous, D., Evans, K. L., Johnstone, E. C., Lawrie, S. M., and Hall, J. (2008). The effects of a neuregulin 1 variant on white matter density and integrity. Mol. Psychiatry 13, 1054-1059.

Mentis, M. J., Sunderland, T., Lai, J. Connolly, C., Krasuski, J., Levine, B. Friz, J., Sobti, S., Schapiro, M., and Rapoport, S. I. (2001). Muscarinic versus nicotinic modulation of a visual task: a PET study using drug probes. Neuropsychopharmacology $25,555-564$. 
Merikangas, A. K, Corvin, A. P., and Gallagher, L. (2009). Copy-number variants in neurodevelopmental disorders: promises and challenges. Trends Genet. 25, 536-544.

Metzker, M. L. (2010). Sequencing technologies - the next generation. Nat. Rev. Genet. 11, 31-34.

Meyer-Lindenberg, A., and Weinberger, D. R. (2006). Intermediate phenotypes and genetic mechanisms of psychiatric disorders. Nature Neurosci. 7, 818-827.

Mitsis, E. M., Cosgrove, K. P., Staley, J. K., Bois, F., Frohlich, E. B., Tamagnan, G. D., Estok, K. M., John P. Seibyl, J. P., and van Dyck, C. H. (2009). Age-related decline in nicotinic receptor availability with [(123)I]5IA-85380 SPECT. Neurobiol. Aging 30, 1490-1497.

Miyajima, F., Quinn, J. P., Horan, M., Pickles, A., Ollier, W.E., Pendleton, N., and Payton, A. (2008a). Additive effect of BDNF and REST polymorphisms is associated with improved general cognitive ability. Genes Brain Behav. 7, 714-719.

Miyajima, F., Ollier, W., Mayes, A., Jackson, A., Thacker, N., Rabbitt, P., Pendleton, N., Horan, M., and Payton, A. (2008b). Brain-derived neurotrophic factor polymorphism Val66Met influences cognitive abilities in the elderly. Genes Brain Behav. 7, 411-417.

Mueller, S. G., Schuff, N., Raptentsetsang, S., Elman, J., and Weiner, M. W. (2008). Selective effect of Apo (4 on CA3 and dentate in normal aging and Alzheimer's disease using high resolution MRI at 4 T. Neuroimage $42,42-48$.

Negash, S., Greenwood, P.M., Sunderland, T., Parasuraman, R., Geda, Y., Knopman, D. S., Boeve, B., Ivnik, R., Petersen, R. C., and Smith, G. E. (2009). The influence of apolipoprotein E genotype on spatial attention dissipates after age 80. Neuropsychology 23, 81-89.

Nemoto, K., Ohnishi, T., Mori, T., Moriguchi,Y.,Hashimoto, R.,Asada, T., and Kunugi, H. (2007). The Val66Met polymorphism of the brain-derived neurotrophic factor gene affects agerelated brain morphology. Neurosci. Lett. 397, 25-29.

Ng, S. B., Buckingham, K. J., Lee, C., Bigham, A. W., Tabor, H. K., Dent, K. M., Huff, C. D., Shannon. P. T., Jabs. E. W., Nickerson, D. A., Shendure, J., and Bamshad, M. J. (2010). Exome sequencing identifies the cause of a Mendelian disorder. Nat. Genet. 42, 30-35.

Nierenberg, J., Pomara, N., Hoptman, M. J., Sidtis, J. J., Ardekani, B. A., and Lim, K. O. (2005). Abnormal white matter integrity in healthy apolipoprotein E epsilon4 carriers. Neuroreport 16, 1369-1372.

Panizzon, M. S., Fennema-Notestine, C., Eyler, L. T., Jernigan, T. L., PromWormley, E., Neale, M., Jacobson, K., Lyons, M. J., Grant, M. D., Franz, C. E., Xian, H., Tsuang, M., Fischl, B., Seidman, L., Dale, A., and Kremen, W. S. (2009). Distinct genetic influences on cortical surface area and cortical thickness. Cereb. Cortex. 19, 2728-2735.

Parasuraman, R., and Espeseth, T. (2007). Genetic and neuroimaging studies of cholinergic and neurotrophic modulation of visual attention. Prog. Nat. Sci. 17, 7-18.

Parasuraman, R., and Greenwood, P. M. (2004). "Molecular genetics of visuospatial attention and working memory," in Cognitive Neuroscience of Attention, ed. M. I. Posner (New York: Guilford), 245-259.

Parasuraman, R., Greenwood, P. M., Kumar, R., and Fosselaa, J. (2005). Beyond heritability: neurotransmitter genes differentially modulate visuospatial attention and working memory. Psychol. Sci. 16, 200-207.

Parasuraman, R., Greenwood, P. M., and Sunderland, T. (2002). The apolipoprotein E gene, attention, and brain function. Neuropsychology 16, 254-274.

Park, D. C., Lautenschlager, G., Hedden, T., Davidson, N. S., Smith, A. D., and Smith, P. K. (2002). Models of visuospatial and verbal memory across the adult life span. Psychol. Aging 17, 299-320.

Park, D. C., and Reuter-Lorenz, P. (2009). The adaptive brain: aging and neurocognitive scaffolding. Annu. Rev. Psychol. 60, 173-196.

Payton, A. (2009). The impact of genetic research on our understanding of normal cognitive ageing: 1995 to 2009. Neuropsychol. Rev. 19, 451-477.

Persson, J., Lind, J., Larsson, A., Ingvar, M., Cruts, M., Van Broeckhoven, C., Adolfsson, R., Nilsson, L. G., and Nyberg, L. (2006). Altered brain white matter integrity in healthy carriers of the APOE epsilon4 allele: a risk for AD? Neurology 66, 1029-1033.

Petrella, J. R., Mattay, V. S., and Doraiswamy, P. M. (2008). Imaging genetics of brain longevity and mental wellness: the next frontier? Radiology 246, 20-32.

Pezawas, L., Verchinski, B. A., Mattay, V. S., Callicott, J. H., Kolachana, B. S., Straub, R. E., Egan, M. F., MeyerLindenberg, A., and Weinberger. D. R. (2004). The brain-derived neurotrophic factor val66met poly- morphism and variation in human cortical morphology. J. Neurosci. 24, 10099-10102.

Pfefferbaum, A., Sullivan, E. V., and Carmelli,D. (2001). Genetic regulation of regional microstructure of the corpus callosum in late life. Neuroreport $12,1677-1681$.

Plassman, B. L., Welsh-Bohmer, K. A., Bigler, E.D., Johnson, S.C.,Anderson,C. V., Helms, M. J., Saunders, A. M., and Breitner,J.C.S. (1996). Apolipoprotein E epsilon 4 allele and hippocampal volume in twins with normal cognition. Neurology 48, 985-989.

Plomin, R., and Crabbe, J. (2000). DNA. Psychol. Bull. 126, 806-828.

Poirier, J. (2000). Apolipoprotein E and Alzheimer's disease: a role in amyloid catabolism. Ann. N. Y. Acad. Sci. 924, 81-90.

Poldrack, R. A. (2008). The role of fMRI in cognitive neuroscience: where do we stand? Curr. Opin. Neurobiol. 18 223-227.

Posner, M. I. (1980). Orienting of attention. Q. J. Exp. Psychol. 32, 3-25.

Posner, M. I. (ed.) (2004). Cognitive Neuroscience of Attention. New York: Guilford, 245-259.

Posner, M. I., and Girolamo, G. J. (1998). "Executive attention: conflict, target detection, and cognitive control," in The Attentive Brain, ed. R. Parasuraman (Cambridge, MA: MIT Press), 401-424.

Posner, M. I., and Petersen, S. E. (1990). The attention system of the human brain. Ann. Rev. Neurosci. 13, 25-42.

Posner, M. I., Rothbart, M. K., and Sheese, B. E. (2007). Attention genes. Dev. Sci. 10, 24-29.

Posthuma, D., De Geus, E. J., Baare, W. F. Hulshoff Pol, H. E., Kahn, R. S., and Boomsma, D. I. (2002). The association between brain volume and intelligence is of genetic origin. Nat. Neurosci. 5, 83-84.

Posthuma, D., Neale, M. C., Boomsma, D. I., and de Geus, E. J. (2001) Are smarter brains running faster? Heritability of alpha peak frequency, IQ, and their interrelation. Behav. Genet. 31, 567-579.

Purcell, S. M., Wray, N. R., Stone, J. L., Visscher, P. M., O’Donovan, M. C. Sullivan, P. F., and Sklar, P. (2009). Common polygenic variation contributes to risk of schizophrenia, and bipolar disorder. Nature 460, 748-752.

Raber, J., Bongers, G., LeFevour, A., Buttini, M., and Mucke, L. (2002). Androgens protect against apolipoprotein E4-induced cognitive deficits. J. Neurosci. 22, 5204-5209.

Raber, J., Huang, Y., and Ashford J. W. (2004). ApoE genotype accounts for the vast majority of $\mathrm{AD}$ risk and
AD pathology. Neurobiol. Aging 25, 641-650.

Reiman, E. M., Caselli, R. J., Lang, S. Y., Chen, K., Bandy, D., Minoshima, S., Thibodeau, S. N., and Osborne, D. (1996). Preclinical evidence of Alzheimer's disease in persons homozygous for the e4 allele for Apolipoprotein E. New Engl. J. Med. 334, 752-758.

Reiman, E. M., Chen, K., Alexander, G. E., Caselli, R. J., Bandy, D., Osborne, D., Saunders, A. M., and Hardy, J. (2004). Functional brain abnormalities in young adults at genetic risk for late-onset Alzheimer's dementia. Proc. Natl. Acad. Sci. U.S.A. 101, 284-289.

Reiman, E. M., Chen, K., Liu, X., Bandy, D., Yu, M., Lee, W., Ayutyanonta, N., Kepplera, J., Reeder, S. A., Langbaum, J. B. S., Alexander, G. E., Klunk. W. E., Mathis, C. A., Price, J. C., Aizenstein, H., DeKosky, S. T., and Caselli, R. J. (2009). Fibrillar amyloid-beta burden in cognitively normal people at 3 levels of genetic risk for Alzheimer's disease. Proc. Natl. Acad. Sci. U.S.A 106, 6820-6825.

Reiman, E. M., Uecker, A., Caselli, R. J., Lewis, S., Bandy, D., de Leon, M. J., De Santi, S., Convit, A., Osborne, D., Weaver, A., and Thibodeau, S. N. (1998). Hippocampal volumes in cognitively normal persons at genetic risk for Alzheimer's disease. Ann. Neurol. 44, 288-291.

Reinvang, I., Lundervold, A. J., Rootwelt, H., Wehling, E., and Espeseth, T. (2009). Individual variation in a cholinergic receptor gene modulates attention. Neurosci. Lett. 453, 131-134.

Reinvang, I., Winjevoll, I. L., Rootwelt, H., and Espeseth, T. (2010a). Working memory deficits in healthy APOE epsilon 4 carriers. Neuropsychologia 48, 566-573.

Reinvang, I., Lundervold, A. J., Wehling, E. I., Rootwelt, H., and Espeseth, T. (2010b). Epistasis between APOE and nicotinic receptor gene in healthy longitudinal cognitive decline. J. Int Neuropsychol. Soc. 16, 424-432.

Rogers, S. W., Gahring, L. C., Collins, A. C., and Marks, M. (1998). Age-related changes in neuronal nicotinic acetylcholine receptor sub-unit alpha4 expression are modified by long-term nicotine administration. J. Neurosci. 18, 4825-4832.

Sabb, F. W., Burggren, A. C., Higier, R. G., Fox, J., He, J., Parker, D. S., Poldrack, R. A., Chu, W., Cannon, T. D., Freimer, N.B., and Bilder, R. M. (2009). Challenges in phenotype definition in the whole-genome era: multivariate models of memory 
and intelligence. Neuroscience 164, 88-107.

Salthouse, T. A. (2009). When does age-related cognitive decline begin? Neurobiol. Aging 30, 507-514.

Schaie, K. W. (2009). "When does agerelated cognitive decline begin?" Salthouse again reifies the "crosssectional fallacy”. Neurobiol. Aging 30, 528-529; discussion 530-533.

Sebat,J.,Lakshmi, B., Malhotra, D., Troge, J., Lese-Martin, C., Walsh, T., Yamrom, B., Yoon, S., Krasnitz, A., Kendall, J., Leotta, A., Pai, D., Zhang, R., Lee, Y., Hicks, J., Spence, S. J., Lee, A. T., Puura, K., Lehtimäki, T., Ledbetter, D., Gregersen, P. K., Bregman, J., Sutcliffe, J. S., Jobanputra, V., Chung, W., Warburton, D., King, M., Skuse, D., Geschwind, D. H., T. Gilliam, C., Ye, K., and Wigler, M. (2007), Strong association of de novo copy number mutations with autism. Science 316, 445-449.

Shaw, P., Lerch, J. P., Pruessner, J. C., Taylor, K. N., Rose, A. B., Greenstein, D., Clasen, L., Evans, A., Rapoport, J., and Giedd, J. N. (2007). Cortical morphology in children and adolescents with different apolipoprotein E gene polymorphisms: an observational study. Lancet Neurol. 6, 494-500.

Shi, J., Levinson, D. F., Duan, J., Sanders, A. R., Zheng, Y. Pe'er, I., Dudbridge, F., Holmans, P. A., Whittemore, A. S., Mowry, B. J., Olincy, A., Amin, F., Cloninger, C. R., Silverman, J. M., Buccola, N. G., Byerley, W. F., Black, D.W., Crowe, R. R., Oksenberg, J. R., Mirel, D. B., Kendler, K. S., Freedman, R., and Gejman, P.V. (2009). Common variants on chromosome 6p22.1 are associated with schizophrenia. Nature 460, 753-757.

Small, B. J., Rosnick, C. B., Fratiglioni, L., and Bäckman, L. (2004). Apolipoprotein E and cognitive performance: a meta-analysis. Psychol. Aging 19, 592-600.

Small, G. W., Siddarth, P., Burggren, A. C., Kepe, V., Ercoli, L. M., Miller, K. J., Lavretsky, H., Thompson, P. M., Cole, G. M., Huang, S. C., Phelps, M. E., Bookheimer, S. Y., and Barrio, J. R. (2009). Influence of cognitive status, age, and APOE-4 genetic risk on brain FDDNP positron-emission tomography imaging in persons without dementia. Arch. Gen. Psychiatry 66, 81-87.

Smit, D. J., Boersma, M., van Beijsterveldt, C. E., Posthuma, D., Boomsma, D. I., Stam, C. J., and de Geus, E. J. (2010). Endophenotypes in a dynamically connected brain. Behav. Genet. 40, 167-177.

Starr, J. M., Fox, H., Harris, S. E., Deary, I. J., and Whalley, L. J. (2007). COMT genotype and cognitive ability: a longitudinal aging study. Neurosci. Lett. $421,57-61$.

Stefansson, H., Ophoff, R. A., Steinberg, S., Andreassen, O. A., Cichon, S., Rujescu, D., Werge, T., Pietilainen, O. P. H., Mors, O., Mortensen, P. B., Sigurdsson, E., Gustafsson, O., Nyegaard, M., Tuulio-Henriksson, A., Ingason, A., Hansen, T., Suvisaari, J., Lonnqvist, J., Paunio, T., Borglum, A. D., Hartmann, A., Fink-Jensen, A., Nordentoft, M., Hougaard, D., Norgaard-Pedersen, B., Bottcher, Y., Olesen, J., Breuer, R., Moller, H., Giegling, I., Rasmussen, H. B., Timm, S., Mattheisen, M., Bitter, I., Rethelyi, J. M., Magnusdottir, B. B., Sigmundsson, T., Olason, P., Masson, G., Gulcher, J. R., Haraldsson, M., Fossdal, R., Thorgeirsson, T. E., Thorsteinsdottir, U., Ruggeri, M., Tosato, S., Franke, B., Strengman, E., Kiemeney, L. A., Melle, I. D. Srdjan, A., Vasily, S., J., de Frutos, R., Bramon, E., Vassos, E., Fraser, G., Ettinger, U., Picchioni, M., Walker, N., Toulopoulou, T., Need, A. C., Dongliang, L. Yoon, J., Shianna, K. V., Freimer, N. B., Cantor, R. M., Murray, R., Kong, A., Carracedo, A., Arango, C., Costas, J., Jonsson, E. G., Terenius, L., Agartz, I., Petursson, H., Nothen, M. M., Rietschel, M., Matthews, P. M., Muglia, P., Peltonen, L., St. Clair, D., Goldstein, D. B., Stefansson, K., and Collier, D. A. (2008). Large recurrent microdeletions associated with schizophrenia. Nature 455, 232-236.

Sublette, M. E., Baca-Garcia, E., Parsey, R. V., Oquendo, M. A., Rodrigues, S. M., Galfalvy, H., Huang, Y., Arango, V., and John, J. J. (2008). Effect of BDNF val66met polymorphism on age-related amygdala volume changes in healthy subjects. Prog. Neuropsychopharmacol. Biol. Psychiatry 32, 1652-1655.

Suh, Y., Atzmon, G., Cho, M. O., Hwang, D., Liu, B., Leahy, D. J., Barzilai, N., and Cohen P. (2009). Functionally significant insulin-like growth factor I receptor mutations in centenarians. Proc. Natl. Acad. Sci. U.S.A. 105, 3438-3442.

Sullivan, E.V.,Pfefferbaum,A., Swan, G.E., and Carmelli, D. (2001). Heritability of hippocampal size in elderly twin men: equivalent influence from genes and environment. Hippocampus 11, 754-762.

Swan, G. E., and Carmelli, D. (2002). Evidence for genetic mediation of executive control: a study of aging male twins. J. Gerontol. B 57, P133-P143.

Tan, H.-Y., Callicott, J.H., and Weinberger, D. R. (2008). Intermediate phenotypes in schizophrenia genetics redux: is it a no brainer? Mol. Psychiatry 13, 233-238.

Taveggia, C., Thaker, P., Petrylak, A., Caporaso, G. L., Toews, A., Falls, D., Einheber, S., and Salzer, J. L. (2008). Type III neuregulin-1 promotes oligodendrocyte myelination. Glia 56, 284-293.

Thompson,P.M.,Cannon, T.D.,Narr,K.L., van Erp, T., Poutanen, V. P., Huttunen, M., Lonnqvist, J., StandertskjoldNordenstam, C., Kaprio, J., Khaledy, M., Dail, R., Zoumalan, C. I., and Toga, A. W. (2001). Genetic influences on brain structure. Nat. Neurosci. 4 1253-1258.

Toga, A. W., and Thompson, P. M. (2005). Genetics of brain structure and intelligence. Annu. Rev. Neurosci. 28, 1-23.

Tohgi, H., Takahashi, S., Kato, E., Homma, A., Niina, R., Sasaki, K., Yonezawa, H., and Sasaki, M. (1997). Reduced size of right hippocampus in 39- to 80-year-old normal subjects carrying the apolipoprotein $\mathrm{E}$ epsilon4 allele. Neurosci. Lett. 236, 21-24.

Tohgi, H., Utsugisawa, K., Yoshimura, M., Nagane, Y., and Mihara, M. (1998). Age-related changes in nicotinic acetylcholine receptor subunits alpha4 and beta 2 messenger RNA expression in postmortem human frontal cortex and hippocampus. Neurosci. Letters 245, 139-142.

Wang, K., Zhang, H., Ma, D., Bucan, M., Glessner, J. T., Abrahams, B. S., Salyakina, Daria, I., M., Bradfield, J. P., Sleiman, P. M. A., Kim, C. E. Hou, C., Frackelton, E., Chiavacci, R. T., Nagahide, S. T., Rappaport, E., Lajonchere, C. M., Munson, J., Estes, A., Korvatska, O., Piven, J., Sonnenblick, L. I., Retuerto, A. I., Herman, E. I., Dong, H., Hutman, T., Sigman, M., Ozonoff, S., Klin A., Owley, T., Sweeney, J. A., Brune, C. W., Cantor, R. M., Bernier R., Gilbert, J.R., Cuccaro, M. L. McMahon, W. M., Miller, J., State, M. W., Wassink, T. H., Coon, H., Levy, S. E., Schultz, R. T., Nurnberger, J. I., Haines, J. L., Sutcliffe, J. S., Cook, E. H., Minshew, N. J., Buxbaum, J. D., Dawson, G., Grant, S. F. A. Geschwind, D. H., Pericak-Vance, M. A., Schellenberg, G. D., and Hakonarson, H. (2009). Common genetic variants on 5 p14.1 associate with autism spectrum disorders Nature 459, 528-533.

Watakabe, A., Sugai, T., Nakaya, N., Wakabayashi, K., Takahashi, H., Yamamori, T., and Nawa, H. (2001). Similarity and variation in gene expression among human cerebral cortical subregions revealed by DNA macroarrays: technical consideration of RNA expression profiling from postmortem samples. Mol. Brain Res. $88,74-82$.

Weiss, L. A., Arking, D. E., Daly, M. J., and Chakravarti, A. (2009). A genomewide linkage and association scan reveals novel loci for autism. Nature 461, 802-808.

Weiss, L. A., Shen, Y., Korn, J. M., Arking, D. E., Miller, D. T., Fossdal, R., Evald Saemundsen, E., Stefansson, H., Ferreira, M. A. R., Green, T., Platt, O. S., Ruderfer, D. M., Walsh, C. A., Altshuler, D., Chakravarti, A., Tanzi, R. E., Stefansson, K., Santangelo, S. L., Gusella, J.F., Sklar, P., Wu, B., and Daly, M. J. (2008). Autism Consortium. Association between microdeletion and microduplication at $16 \mathrm{p} 11.2$ and autism. N. Engl. J. Med. 358, 667-675.

Wellcome Trust Case Control Consortium. (2007). Genome-wide association study of 14,000 cases of seven common diseases and 3,000 shared controls. Nature 447, 661-678.

Westlye, L. T., Walhovd, K. B., Dale, A. M., Bjørnerud,A., Due-Tønnessen, P., Engvig, A., Grydeland, H., Tamnes, C. K., Ostby, Y., and Fjell, A. M. (2010). Life-span changes of the human brain white matter: diffusion tensor imaging (DTI) and volumetry. Cereb. Cortex 20 , 2055-2068.

Wibrand, K., Messaoudi, E., Havik, B. Steenslid, V., and Lovlie, R. (2006). Identification of genes co-upregulated with Arc during BDNF-induced longterm potentiation in adult rat dentate gyrus in vivo. European J. Neurosci. 23, 1501-1511.

Winterer, G., Konrad, A., Vucurevic, G., Musso, F., Stoeter, P., and Dahmen, N. (2008). Association of $5^{\prime}$ end neuregulin-1 (NRG1) gene variation with subcortical medial frontal microstructure in humans. Neuroimage 40 , 712-718.

Wisdom, N. M., Callahan J. L., and Hawkins, K. A. (2009).The effects of apolipoprotein $\mathrm{E}$ on non-impaired cognitive functioning: a meta-analysis. Neurobiol. Aging 12 [Epub ahead of print].

Wishart, H. A., Saykin, A. J., McAllister, T. W., Rabin, L. A., McDonald, B. C., Flashman, L. A., Roth, R. M., Mamourian, A.C., Tsongalis, G. J., and Rhodes, C. H. (2006). Regional brain atrophy in cognitively intact adults with a single APOE epsilon4 allele. Neurology 67, 1221-1224.

Witte, A. V., Fobker, M., Gellner, R., Knecht, S., and Flöel, A. (2009). Caloric restriction improves memory 
in elderly humans. Proc. Natl. Acad. Sci. U.S.A. 106, 1255-1260.

Yankner,B.A.Lu, T,andLoerch,P.(2008).The aging brain. Annu. Rev. Pathol. 3, 41-66.

Yantis, S., Schwarzbach, J., Serences, J. T., Carlson, R. L., Steinmetz, M. A., Pekar, J. J., and Courtney, S. M. (2002). Transient neural activity in human parietal cortex during spatial attention shifts. Nat. Neurosci. 5, 995-1002.

Conflict of Interest Statement: The authors declare that the research was conducted in the absence of any commercial or financial relationships that could be construed as a potential conflict of interest.
Received: 07 April 2010; accepted: 17 September 2010; published online: 02 November 2010.

Citation: Reinvang I, Deary IJ, Fjell AM, Steen VM, Espeseth T and Parasuraman $R$ (2010) Neurogenetic effects on cognition in aging brains: a window of opportunity for intervention? Front. Ag. Neurosci. 2:143 doi: 10.3389/fnagi.2010.00143
Copyright $\odot 2010$ Reinvang, Deary, Fjell, Steen, Espeseth and Parasuraman. This is an open-access article subject to an exclusive license agreement between the authors and the Frontiers Research Foundation, which permits unrestricted use, distribution, and reproduction in any medium, provided the original authors and source are credited. 